\title{
Military Deployments and Children's Academic Achievement: Evidence from Department of Defense Education Activity Schools
}

\author{
Working Draft as of 20 December 2006 \\ Rozlyn C. Engel, Luke B. Gallagher, and David S. Lyle \\ U.S. Military Academy
}

Lengthy and frequent overseas deployments since 2002 are widely perceived to have placed considerable pressures on military personnel and their families. Combining the standardized test scores of children enrolled in Defense Department schools with their military parent's Army personnel data, we evaluate the effect of a soldier's deployment on the academic achievement of his or her children. We find that deployments have modest adverse effects across most academic subjects, with lengthy deployments and deployments during the month of testing leading to the largest detrimental effects. Further evidence suggests that the adverse effects in academic achievement may persist for several years.

The views expressed herein are those of the authors and do not purport to reflect the position of the U.S. Military Academy, the Department of the Army, or the Department of Defense. 


\section{Introduction}

Prompted by the demands of the Global War on Terror (GWOT), in combination with ongoing security commitments around the globe, the U.S. military has deployed large numbers of troops overseas in the past five years. In 2004 alone, the Department of Defense (DoD) reports that 1,157,647 members of all services and components deployed away from their home base, about 45 percent of total end-strength. ${ }^{1}$ To Afghanistan and Iraq, the United States is estimated to have deployed 1,048,884 troops between late 2001 and January $2005 .^{2}$ The U.S. Army, for example, went from having 8 percent of its force deployed in 2001 to having more than 36 percent deployed in 2005. During this time, the average deployment has become significantly longer with an increase in average duration of more than $50 \%{ }^{3}$ Under current operational conditions, the average Army soldier can expect to spend almost half of his or her four-year enlistment period in a deployed status.

There is a growing conviction that the increased intensity of deployments has created worrisome levels of stress on military members and their families. In November 2006, General John Abizaid, the head of U.S. Central Command and military commander for the entire Middle East, testified before the U.S. Senate Committee on Armed Services that "the ability to sustain that commitment [of an modest increase in U.S. troop levels] is simply not something that we have right now, with the size of the Army and the Marine Corps." In December 2006, General Schoomaker, the Chief of Staff of the U.S. Army, warned that the U.S. Army would "break" without more soldiers. Several days later, President Bush announced his inclination to increase

\footnotetext{
${ }^{1}$ See U.S. Department of Defense (2005) for more detailed information on deployments.

${ }^{2}$ See Benjamin (2005) for a comprehensive discussion on deployments in a historical context.

${ }^{3}$ Based on authors' tabulations from the Total Army Personnel Database and the Army Active Duty Pay File from October 2000 through September of 2005.
} 
the end-strength of the Army and Marines, citing concerns about the readiness of U.S. forces in the current operational environment. ${ }^{4}$

The sense that the nation is depleting its military personnel has significant implications for national security. Since 1974, the nation has structured its military force around the AllVolunteer Force. A further sign of the strain on the All-Volunteer Force is that fact that the Army spent about $\$ 735$ million on retention bonuses in 2006, nearly $\$ 650$ million more than in 2003. It also had significantly higher recruiting costs this year than last year, with more marginal ability accessions as well. ${ }^{5}$ Understanding the sources of strains on military members and addressing them through well-designed policy is of profound importance for the viability of the AVF and troop readiness of the United States.

Deployments place a variety of stresses on military personnel, from emotional to financial. Not surprisingly, for military personnel with children, the welfare of their dependents becomes a common and frequently pressing concern during a deployment. More than 25 percent of military households have school-age children, and between 2002 and 2006, some 132,154 children of Army soldiers have experienced a parental absence due to a deployment. ${ }^{6}$ Parental absences_-particularly military deployments to hostile theatres—can prompt feelings of anxiety, loneliness, and helplessness. For example, in the March 2005 Survey of Active-Duty Military, conducted by the Defense Manpower Data Center, only 6 percent of the active-duty members responding to the survey actively disagreed with the following statement: "Deployments increase the likelihood of problems at school.” Nearly one-third strongly agreed with that statement. ${ }^{7}$

\footnotetext{
${ }^{4}$ Abizaid quote is as reported by Ricks and Tyson, 2006. See Schoomaker (2006, p.5) for formal remarks. See Baker, Fletcher, \& Abramowitz (2006) for more information on President Bush's remarks.

${ }^{5}$ For more information on accessions numbers see Jaffe, 2006.

${ }^{6}$ Based on authors' tabulations from the Total Army Personnel Database, Army Active Duty Pay File, and the Dependent Eligibility Enrollment Reporting System as of 30 September 2005.

${ }^{7}$ Defense Manpower Data Center (2005, question 57).
} 
In this paper, we consider how deployments affect the academic performance of children from military families. We aim to test the perception that a parent's deployment creates stress on children (as captured by academic outcomes) and offer a set of estimates to guide the design of future policy interventions. We use the standardized test scores and personal characteristics of a sample of some 56,000 observations for school-age children who were enrolled in Department of Defense schools between 2002 and 2005. To each child's academic records, we add administrative data on the military parent's service record, including deployment information during that period. We focus our analysis exclusively on children of enlisted personnel from Army households. ${ }^{8}$

This study builds on work by Pisano (1992), Angrist and Johnson (2000), and Lyle (2006), all of which look at how deployments affect military households. We are able to improve on these studies in several important ways. First, our sample represents a larger and broader geographical distribution of children than in previous studies. Pisano (1992) had only 158 observations when he showed that sixth-grade girls exhibited slightly lower academic performance when a parent was deployed. Angrist and Johnson (2000) used self-reported survey data from the 1992 Survey of Officers and Enlisted Personnel and looked primarily at how deployments affect marital dissolution and spousal labor market participation. They did examine one outcome at the child level, disability rates, but found no effect. Second, we assess academic achievement in five distinct subject areas—math, science, language arts, social studies, and reading — as well as a total composite score. Pisano (1992), by comparison, looked only at reading scores. Lyle (2006), with a larger sample of nearly 13,000 observations on military children living in Texas, looked only at math scores. Third, we assess multiple dimensions of a

\footnotetext{
${ }^{8}$ Administrative data are available only for Army personnel. In addition, differences in military experiences and educational attainment between officers and enlisted soldiers make direct comparisons difficult. Therefore, we restrict our analysis to the disproportionately larger enlisted population.
} 
deployment: any deployment in the past year (the contemporaneous school year, as defined below), months deployed during the past year, duration of the deployment during the past five years, and the timing of the deployment relative to the exam date. Finally, this is the only study, to our knowledge, that looks at how deployments in the post-September 11 world affect military children.

In regressions from ordinary least squares (OLS) specifications, we find that an enlisted parent's deployment in the past year reduces his or her child's total test score by 0.42 percentage points (using a norm-referenced grading scale of 1 to 99 percent). We estimate the marginal effect of an additional month of deployment to be 0.11 percentage points. From more disaggregated results, we find that the effects are most significant for math and science; they are less pronounced, though often statistically significant, for language arts, social studies, and reading. We find the largest adverse effects for young children, boys, minorities, children whose parents are married, children whose parents have lower AFQT scores, and children whose parents have lower levels of education.

Our identification strategy must address several challenges that could complicate the interpretation of our estimates. One concern is the possibility that a parent's deployment status may not be orthogonal to other potential determinants of his or her child's academic performance. For example, many of the parents who volunteer to deploy may be the same ones with the lowest academic expectations for their children when they are away. Conversely, parents who resist a deployment may be the same ones who take the most care to prepare their children for the separation. A second concern is that the Army may select certain soldiers to deploy based on characteristics that are also correlated with the academic achievement of their children. A third concern stems from potential endogeneity in the length of a deployment: it is 
possible that a soldier is sent home from a deployment prematurely as a result of problems in the home that are also correlated with a child's academic achievement. In each case, we must contend with a correlation between a parent's deployment history and some unobserved determinant of the child's subsequent academic achievement.

In general, the Army's mechanisms for assigning deployments, in conjunction with its culture of "serving at the needs of the Army," weigh against these concerns. Nonetheless, we also present econometric evidence to validate our interpretation of these estimates. We control for many observable variables that are potential determinants of a child's academic achievement and that are also potentially correlated with deployment assignments. We also test the exogeneity of individual-level deployments using a set of instrumental variables based on unitlevel deployments. The resulting two-stage least squares (2SLS) estimates reinforce our claim that military deployments are uncorrelated with other potentially confounding determinants of children's academic achievement.

We also show that the timing of the deployment matters. The standardized test for which we have outcomes is administered during the month of March. A parent's deployment during March lowers a child's total test score by 0.75 percentage points, relative to those children in our sample who do not have a parent deployed during that month. By contrast, if a parent's deployment ends in the late summer or early fall of the academic school year-that is, at least four months before the test is administered—-then the child displays no statistically significant reduction in his or her test score. For children whose parents have deployed for more than twelve months over the past five years, we find a small reduction in their total test score (approximately 1 percentage point) relative to those children whose parents did not deploy at all 
in the past five years. Further evidence suggests that the adverse effects persist for at least four years from the time of the deployment.

Together, the findings suggest that children suffer a small but persistent academic penalty when their parents deploy. We believe that, in light of these results, schools would be justified in offering additional academic and emotional support to children during a parent’s deployment, and perhaps for some time after the parent returns. These estimates also provide useful insights into how to design those support programs most effectively, from focusing on the most vulnerable subpopulations, to pinpointing the subject areas that pose the greatest difficulty during a parent's absence, to noting the timing of a military parent's deployment and making possible adjustments in the test scores of his or her child. Above all, we believe that these results can inform the national debate about the full costs of deployments, their impact on the welfare of military households, and the vitality of the All-Volunteer Force.

The next section contains background information on the DoD school system and its methods of assessing student performance, including its use of standardized tests. It also describes the administrative personnel data available from the U.S. Army and the summary statistics of the matched child-parent data. Section III lays out our empirical strategy and baseline specifications. Section IV contains the main results. Section V offers policy implications and concludes.

\section{Background and Data}

A. Department of Defense Educational Activity (DoDEA) 
The Department of Defense has provided "on post” schools for selected military bases in the United States and abroad since the end of the Second World War. ${ }^{9}$ The entire school system, which is administered by the Department of Defense Educational Activity (DoDEA), comprises 223 schools in 7 U.S. states, 2 U.S. territories, and 13 foreign countries. It contains 104,935 students from pre-kindergarten to $12^{\text {th }}$ grade, though not every DoDEA school houses all 14 grade levels. Within DoDEA schools, about 45 percent of the students are from Army households. We have 56,116 observations for children who were in the DoDEA system between 2002 and 2005 and who had an enlisted parent in the active-duty U.S. Army. ${ }^{10}$

DoDEA administers the Terra Nova Multiple Assessment Test in March of each year. Widely used across the United States, the Terra Nova is a set of norm-referenced testing instruments published by CTB/McGraw-Hill for grades 2 through $11 .{ }^{11}$ The Terra Nova asks a battery of questions designed to "measure concepts, processes, and objectives taught throughout the nation.” The majority of the questions are traditional "selected-response” questions (multiple choice); on a multiple assessment test, some "open-ended" questions are also included. DoDEA begins its testing in grade 3 and uses the results to assess the performance of DoDEA students in relation to national averages for each grade level.

All children within the DoDEA system must take the Terra Nova test, and their results are reported directly to DoDEA. ${ }^{12}$ It is worth noting that our main regressions include only mainstream children, though we explore similar issues for the non-mainstream population in a

\footnotetext{
${ }^{9}$ Overseas schools were established after the war; many domestic schools were begun earlier. A brief history of the DoDEA system is offered in U.S. Department of Defense Education Activity (2004). Other general information about the agency can be found in U.S. Department of Defense Education Activity (2003, 2006)

${ }^{10}$ More information about DoDEA schools can be found at http://www.dodea.edu.

${ }^{11}$ See CTB/McGraw Hill (2000) for more details.

${ }^{12}$ Children who have been approved for "an alternate assessment" may be exempt from taking the Terra Nova (from DoDEA website, http://www.dodea.edu/instruction/support/accountability/assessment2.htm, accessed on July 20, 2006). Note that children within DoDEA schools have performed better than the national average in all subject areas.
} 
set of supplementary regressions. ${ }^{13}$ For each child, we observe a total score and five sub-scores in math, science, language arts, social studies, and reading. To assist with the interpretation of student scores, the publisher of the Terra Nova has created several norm-referenced measures of performance such as the national percentile score, objective performance score, normal curve equivalent score, and national stanine score. For our analysis, we use the normal curve equivalent (NCE) because it is the only metric that is an equal interval score making it appropriate for use in regression analysis. ${ }^{14}$ The NCE score can range from 1 to 99, making for a Altonji, Joseph, Todd Elder, and Christopher Taber. 2000. "Selection on Observed and Unobserved Variables: Assessing the Effectiveness of Catholic Schools.” NBER Working Paper 7831. Cambridge, MA: National Bureau of Economic Research.

\section{B. Deployment Assignments}

The unit to which a soldier is assigned and that unit's subsequent missions largely determine the frequency and duration of a soldier's deployment. To establish that a soldier's probability of deployment is largely exogenous to the academic achievement of his or her children, we briefly describe the mechanisms by which personnel are assigned to particular units and how deployment decisions affecting that unit are made.

Upon completion of a soldier's basic training, the Army’s Human Resources Command assigns him or her to an initial unit; every three to four years, it reassigns the soldier to a different unit. The Army makes those assignments based on the "needs of the Army," which are driven primarily by world events and national-level defense policy. ${ }^{15}$ Like the assignment mechanism, deployment orders also follow from the "needs of the Army” and they rotate between units accordingly. In the years encompassed in this study, the Global War on Terror has mainly defined "the needs of the Army." Although we believe that such macro-level concerns are not likely to be correlated with the academic achievement of individual military children, we

\footnotetext{
${ }^{13}$ Non-mainstream children include children with learning disabilities, physical disabilities, special testing or learning accommodations, and English as a second language. We present some findings for non-mainstream children in Appendix Tables 4 through 6.

${ }^{14}$ To create its norm-referenced scores, CTB/McGraw Hill constructs a random national sample that accurately represents the test-taking population and then uses it to evaluate the performance of an individual child relative to the national norm. The national norm is conditioned on geographic region, school size, socioeconomic status, race, ethnicity, and type of school. See CTB/McGraw Hill (2000) for more details.

${ }^{15}$ Lyle (2006) has additional details about the military assignment mechanisms.
} 
test this assumption using a set of instrumental variables, as well as a set of control variables.

We provide a fuller discussion of our identification strategy in Section III.

\section{Combining Military Data with DoDEA Data}

Soldiers deployed to designated regions around the world receive a form of supplemental compensation called hostile fire pay (HFP). We use HFP data for Army personnel to determine the number of months that a soldier is deployed and the dates of any deployment. ${ }^{16}$ Hostile fire pay is the most reliable source for deployment data because the soldier will ensure that he or she gets paid and the Army will ensure that the pay is correct. We start by defining the current school year as August 1 of the calendar year preceding the test through March 31 of the year in which the test is taken. We then construct several deployment variables from HFP pay data: ever deployed equals one if the military parent received any HFP during the current school year and zero otherwise; months deployed equals the number of months that the military parent received HFP during the current school year (its value ranges from zero to eight); and several variables are constructed to capture the precise months during which a military parent was receiving HFP. From additional administrative data, we also observe the child's gender and race, as well as the military parent's gender, marital status, education level, occupational specialty, and AFQT score.

We merge the DoDEA and administrative data using the child's social security number, yielding a final matched data set at the level of the individual child. ${ }^{17}$ Table 1 displays descriptive statistics for the children and parents in our sample. Panel A offers the means and standard deviations for the full sample of 56,116 observations. Overall, the students in our

\footnotetext{
${ }^{16}$ We calculate the number of months that a soldier is deployed by dividing the sum of all HFP received over a designated period of time by the monthly HFP allotment.

${ }^{17}$ Data are matched by child and year of exam. Appendix Table 1 shows that the children in our DoDEA sample are highly representative of the overall population of children whose parents are in the Army.
} 
sample earned an average total NCE score of 57.07 (on a scale of 1 to 99), with a standard deviation of 14.14. Our sample is equally divided between boys and girls; about one-third of the children are black; more than 90 percent have married parents; more than one-quarter have parents with at least some post-secondary education; about one-third have a parent with an AFQT score placing them in the top half of the ability distribution; and about 60 percent serve in combat support occupations.

Panel B compares children with parents who deployed to children whose parents did not deploy during the current academic school year. About 26 percent of the children had a parent deploy in the current school year. Panel C compares children with parents who deployed for various durations during the current school year. Panel D considers whether the parent was deployed at the time of the test. Approximately 17 percent of the children had a parent deployed at the time of the exam. All three panels show that a child's math score declines as the duration of the parent's deployment increases, though scores in other subjects appear to rise slightly in Panels B and C. Only a deployment during the month of the test (in Panel D) appears to be consistently negatively correlated with test scores across the range of subjects. In Panel E, we provide summary statistics for the cumulative effect of a parent's deployment history. ${ }^{18}$ The academic achievement scores show similar results.

One notable feature of the data is the relatively comparable means for the remaining descriptive variables across the various measures of a parent's deployment status, suggesting the widespread and indiscriminate nature of current Army deployments. However, to explore the small correlations between the deployment variables and some of the control variables, we provide regression estimates in Appendix Table 2. After controlling for child race, child gender,

\footnotetext{
${ }^{18}$ This sample contains only children whose parents have been in the Army for at least five years, resulting in 51,362 observations.
} 
and child grade, the remaining covariates explain only 1 to 2 percent of the total variation in deployment status for all deployment variables.

\section{Empirical Framework}

To investigate more formally how military deployments affect the academic achievement of military children, we employ a basic linear model using pooled data from 2002 through 2005:

$$
A_{i t}=\alpha+\theta_{t}+\lambda_{i t}+\delta \cdot D_{i t}+\beta \cdot X_{i t}+\varepsilon_{i t}
$$

Here the left-side variable, $A_{i t}$, is one of the following outcomes: the NCE score in math, science, language arts, social studies, reading, or the total composite score across all five subjects. The $\alpha$ term is a constant; $\theta_{t}$ are year dummies for 2003-2005; and $\lambda_{i t}$ are dummies for grade levels 4 through 11. The coefficient $\delta$ on the variable of interest, $D_{i t}$, represents the effect of a military parent's deployment on the NCE scores of his or her child $i$ in time period $t$. The vector $X_{i t}$ captures other covariates including the child's gender and race, as well as the marital status, gender, civilian education level, AFQT score, and occupational specialty of the child's military parent. We cluster all standard errors for OLS estimates at the level of the individual child, using Huber-White robust standard errors.

Based on the process of military assignments, the primary threat to the validity of our identification assumption is the possibility that a soldier's deployment may correlate with his or her child's academic achievement. As a first step toward addressing this concern, we control for all observable characteristics that the Army could use to assign soldiers to deployments. For example, the Army could weigh the AFQT score of a soldier when making its deployment decisions, and the AFQT score of the military parent could be correlated with the child's academic performance during that parent's deployment. Fortunately, our data contain nearly all of the individual-level characteristics available to the Army for making deployment assignments 
(including AFQT scores). We therefore include them in our regressions to strengthen the case for a causal interpretation.

We also construct instrumental variables to test our claim that parental assignments are exogenous. By way of background, Figure 1 presents an organizational chart for a typical Army division. For two of our deployment metrics, we construct instruments using unit-level deployment data. The instrument for ever deployed follows Lyle (2006): we assign a one to each child who had a parent assigned to a battalion that had more than one-third of its soldiers deploy during the current school year. ${ }^{19}$ The instrument for months deployed is the average number of months deployed for all soldiers assigned to a unit. ${ }^{20}$ We anticipate a positive correlation between unit-level months deployed and individual-level months deployed because soldiers assigned to units with longer deployment durations are more likely to deploy for longer periods than soldiers assigned to units with shorter deployment durations. The exclusion restriction for this instrument seems reasonable because a unit's deployment duration is not likely to be correlated with the academic achievement of an individual soldier's child.

Panel C of Appendix Table 2 shows the covariate regressions between the two deployment instruments and the control variables. Of particular note, the pattern of correlations between individual-level controls and individual-level deployment variables are mirrored in the correlations between the individual-level controls and the unit-level deployment instruments (compare Panels A and C). Yet, the sizes of the correlations are smaller in Panel C. Moreover,

\footnotetext{
${ }^{19}$ As in Lyle (2006), we use the ratio of one-third because most battalions consist of three main companies, any one of which can be deployed separately as part of a task force. There is likely to be a positive correlation between unitlevel and individual-level deployments because a soldier in a unit that receives a deployment order is more likely to deploy than if his or her battalion does not receive a deployment order. We maintain that a superior-level commander's selection of which company deploys as part of a task force is likely uncorrelated with the individuallevel educational achievement of the soldiers' children in that company.

${ }^{20}$ We use this instrument to test if the "months deployed" variable is endogenous: if a soldier returns early from a deployment to handle family problems and those problems correlate with a child's academic achievement, then months deployed could be endogenous.
} 
after controlling for child characteristics, the remaining parental characteristics explain less than 1 percent of the total variation in unit-level deployments, further supporting the validity of our exclusion restriction. Accordingly, it seems reasonable that superior commanders assign unitlevel deployments based on "the needs of the Army," which are not likely related to individuallevel determinants of a child's academic achievement.

\section{Empirical Results}

Table 2 contains OLS and 2SLS estimates of the impact of a parent's deployment during the current school year on a child's total NCE score. Following Equation (1), all regressions contain a constant term, a set of dummy variables for the years 2003 through 2005, and a set of dummy variables for grades 4 through 11. Panel A shows results for the ever deployed variable; Panel B shows the results for the months deployed variable. In the first column of each panel, we present a basic specification, in which we estimate the effect of the respective variable without any child or parent control variables. In the second column, we add child characteristics. In the third column, we include child and parental characteristics that are likely correlated with academic achievement and possibly correlated with the deployment variables.

Before discussing the main results for deployment effects, it is instructive to highlight the coefficients on the child and parental control variables in the third columns of both panels. These estimates suggest that boys score two points lower than girls; white children score significantly higher than black children and about one point higher than children of other races; children with married parents score higher than children with single parents; children with a male parent in the Army score higher than children with a female parent in the Army; children with parents who have more education score higher than children with parents who hold a high school degree or lower; children with high-ability parents (in Category 1 or 2 of the AFQT distribution) 
score almost three points higher than children with middle-ability parents (in Category 3A of the AFQT distribution); and children with low-ability parents (in Category 3B, 4, or 5) score more than two points lower than children with middle-ability parents. On balance, these estimates seem reasonable and conform with previous estimates found in Lyle (2006).

Next, we turn to the estimated coefficients in Panel A, showing the results for the ever deployed variable. Estimates of $\delta$ from the parsimonious specification in column (1) change significantly when we include exogenous child controls in column (2). There is only a slight change in the estimated deployment effect, however, when we add the parental characteristics in column (3). This result suggests that once exogenous child characteristics are included, the estimates are quite stable. In other words, parental characteristics, which the Army could theoretically use to assign deployments, have little effect on the estimated treatment effect. The relative stability of $\delta$ also suggests that the effect of other less relevant unobserved variables should be quite minor. ${ }^{21}$ Finally, from the estimates in column (3), a child whose parent deploys during the current school year scores 0.42 percentage points, or 3 percent of a standard deviation, lower on his or her total Terra Nova score than a child whose parent does not deploy.

To test whether we can apply a causal interpretation to these results, we estimate a 2SLS specification using the unit-level instrumental variable described earlier. As column (4) shows, the sign on the first stage of this specification is positive and significant: a child whose parent was assigned to a unit in which more than one-third deployed was 69.8 percent more likely to have his or her parent deploy than a child whose parent was assigned to a unit in which less than one-third deployed. The partial $\mathrm{R}^{2}$ on the first stage is 0.28 , which means that the instrument explains approximately $28 \%$ of the variation in individual-level deployments. A Hausman

\footnotetext{
${ }^{21}$ Altonji, Elder, and Taber (2000) argue that the size of the effect on the variable of interest when relevant observable variables are included is a useful informal test of the extent to which other unobservable characteristics may bias estimates.
} 
specification test fails to reject the null hypothesis that the OLS estimates are statistically equivalent to the 2SLS estimates. ${ }^{22}$

Moving to Panel B of Table 2, we observe how the length of a parent's deployment during the current school year, measured by months deployed, affects a child's academic performance. Again, we see that estimates of $\delta$ are only slightly sensitive to the inclusion of the parental control variables. Likewise, 2SLS estimates in column (4) and results from the Hausman test support our exogenous deployment assumption. Estimates in column (3) indicate that a one-month increase in the length of a parent's deployment reduces a child's total NCE score by 0.11 percentage points. One implication of this finding is that a deployment spanning the full eight months preceding the test would reduce the total NCE score by 0.88 percentage points, or 5 percent of a standard deviation.

Thus far, our results - especially the stability of the estimated deployment effects and the 2SLS results—provide strong evidence that military deployments offer a plausible source of exogenous variation. Accordingly, we use OLS to estimate Equation (1) for the remainder of this paper, consistently employing the full set of child and parent control variables. ${ }^{23}$

Table 3 extends the analysis by showing the effects of a broader set of deployment metrics on the five separate subject areas tested by the Terra Nova. Each estimate is from a separate OLS regression with the full set of control variables. The ever deployed variable displayed in Panel A is statistically significant for math, science, and language arts scores. A parent's deployment during the current school year lowers a child's math NCE score by 0.76 percentage points, nearly twice the effect on the total NCE score. A similar pattern holds for the

\footnotetext{
${ }^{22}$ See Table 2 notes for the Hausman test p-values. All are insignificant at the 95 percent confidence level.

${ }^{23}$ We provide additional robustness checks in Appendix Table 3 by dropping observations from certain demographic groups to further demonstrate that our estimates remain stable across different samples.
} 
months deployed variable in Panel B; an eight-month deployment lowers a child's math score by 1.504 percentage points compared with 0.88 for the total NCE score.

Panels C and D in Table 3 test whether the timing of the deployment bears on a child's performance on the standardized tests. In Panel C, $D_{i t}$ equals one for a child whose parent was deployed during March (the month of the exam) and a zero otherwise. Here we find a negative and statistically significant effect across all five subjects and for the total composite score. A child whose parent was deployed during March of the current school year experiences a 0.92 percentage point reduction in his or her math score relative to a child whose parent was not deployed during that time — the largest single effect estimated for deployment during the current school year.

A logical follow-up question is how the timing of a parent's deployment throughout the academic school year affects a child's test scores. Therefore, in Panel D, $D_{i t}$ contains a set of new dummy variables: the first for a child whose parent returned from a deployment between August and October; the second for a child whose parent returned from a deployment between November and January; and the last for a child whose parent returned from a deployment in February or was still deployed in March. The omitted category is children whose parent did not deploy at any point during the current school year. In these results, we see that a child whose parent returned between August and October scored about the same as a child whose parent did not deploy that year. However, a child whose parent returned between November and January scored 0.79 percentage points lower in math and 0.66 percentage points lower in science than a child whose parent did not deploy that year. Finally, we see that a child whose parent returned in February or was still deployed in March experienced the largest adverse effects: in three of the 
five subject areas and in the total score, that child scored lower than a child whose parent did not deploy that year.

On balance, these findings suggest at least two interpretations. We call our first interpretation the “disruption” effect. The estimates in Panels A through C suggest that a parental deployment disrupts a child’s academic performance in the classroom, particularly if the absence occurs during the month in which the child is tested. The estimates in Panel D lead to our second interpretation, a "catching up” effect. It appears that a parent who returns earlier in the school year has time to restore stability to the family before a child takes the Terra Nova exam in March. This provides some evidence that children who fall behind in the classroom during a parent's deployment suffer only a temporary "penalty” relative to their peers; once the parent returns, the penalty appears to dissipate over time.

To explore our two interpretations further, we estimate how a soldier’s deployment history over the past five years affects his or her child's academic achievement. We organize Table 4 in a manner similar to Table 3, but we restrict our sample to children whose military parent has been in the Army for at least five years. The estimates in Panel A are from an OLS regression with a full set of child and parental controls; the deployment metric of interest is ever deployed in the last five years, which equals one if the parent received HFP at any point during the five years preceding the test and zero otherwise. For all five subjects and the total score, we observe a statistically significant negative effect, suggesting that these children experience a residual decline in academic achievement that can be observed over time. The estimates for the months deployed in the past five years further support this interpretation. As seen in Panel B, the effects are statistically significant for all six outcome measures. For this more restricted sample, the effect of months deployed is smaller than that found for our larger sample, which was 
estimated for the current school year only. Taken together, these results provide suggestive evidence that the penalty associated with deployments becomes less acute as time passes, but does not fully dissipate.

To assess this notion of an incomplete “catching up” effect, we present estimates in Panel C from an OLS regression where $D_{i t}$ contains a set of dummy variables: the first for a child whose parent returned from his or her last deployment within a year of the test date; the second for a child whose parent returned from his or her last deployment one to two years before the test date; the third for a child whose parent returned from his or her last deployment two to three years before the test date; the fourth for a child whose parent returned from his or her last deployment three to four years before the test date; and the fifth for a child whose parent returned from his or her last deployment four to five years before the test date. The omitted category in each specification is children whose parents never deployed in the past five years. For nearly all of the test subjects, deployment effects persist for up to four years after a parent returns from a deployment.

Although our estimates of the short-term effects of deployments during the current school year are relatively small, the persistence of the adverse effects over time may be cause for concern. In particular, for young children, the cumulative long-term effects of repeated deployments could become substantial by the time a child reaches the $11^{\text {th }}$ grade. Table 5 contains estimates from specifications using our full sample that assess the extent to which age and other characteristics may make children more vulnerable to the academic setbacks associated with deployments. Panel A of Table 5 presents the effects of months deployed, and Panel B presents the effects of deployed in March. All of these estimates pertain to deployments during the current school year and are most directly comparable to estimates in Tables 1 through 3. 
The age at which a child is exposed to a parent's deployment appears to matter: elementary-age children generally score worse than secondary-age children as the length of parent's deployment during the current school year increases. Both seem adversely affected by a deployment during the month of the exam. Male children appear to do worse than female children as the length of a parent's deployment increases and when deployments occur during the month of March. Minority children do worse than white children as the duration of deployment increases but do about the same if the parent is deployed during the month of the exam.

With respect to the parental control variables, children whose mother is deployed and children whose single parent is deployed do no worse than the control group. By contrast, children whose father is deployed and children whose married parent is deployed do experience an adverse effect on their test scores. This result may suggest that "traditional" households experience a greater sense of disruption during a parent's deployment, as the newly "single" parent at home strives to fill new roles within the household. ${ }^{24}$ Alternatively, children who live in single parent households may already have developed coping mechanisms to deal with parental absences and the consequent increase in household responsibilities.

In Table 6, differences in parental ability, as measured by the AFQT, have little apparent effect on how a child performs when his or her parent deploys. However, deployments do seem to have a greater adverse effect on a child whose parent holds only a high school diploma or less as compared with a child whose parent has at least some college. This may reflect the lower importance that these parents place on education or may reflect a lower predisposition in these children to pursue academic endeavors in the wake of a deployment.

\section{Policy Implications and Conclusions}

\footnotetext{
${ }^{24}$ In a related work, Angrist and Johnson (2000) found that women who deployed during the Persian Gulf War of the early 1990s experienced higher rates of marital dissolution than men who deployed.
} 
We have presented a set of robust estimates of the effect of a parent's deployment on a child's academic performance. Our analysis offers valuable new insights into the effects of parental absences across numerous academic subjects and across age groups. We also carefully consider the duration and the timing of a parent's deployment, adding considerably to the current knowledge of how deployments are likely to affect the hundreds of thousands of children whose parents are currently serving in the U.S. military. With this knowledge, the question of how deployments are affecting the welfare of dependents can be partially answered, and we can begin to formulate policies that safeguard the future of the All-Volunteer Force. ${ }^{25}$

On one level, our regression results show that the effects of a parental deployment during the current school year are modest and tend to dissipate to some extent after a parent's return. We also find that certain academic subjects pose more trouble for a child whose parent has deployed and that longer deployments and deployments during the month of the exam exacerbate those effects. Together, these findings suggest that schools should carefully track the deployments of parents and design short-term academic interventions-particularly, within math and science arenas—-to support children during these critical periods. ${ }^{26}$ Schools might also consider using these results to better interpret the test scores of a child whose parent has deployed, especially if the scores are being used for class placement and other diagnostic purposes.

On another level, however, the paper delivers some cautionary evidence. The cumulative effects of a parent's deployment linger over time, implying that children whose parents deploy face the risk of falling permanently behind their peers, both military and civilian. Of particular

\footnotetext{
${ }^{25}$ Our results are remarkably similar to those reported by Lyle (2006), who used an entirely different sample of children from military households, bolstering the reliability of the estimates and enhancing their policy relevance. ${ }^{26}$ Emotional, social, and psychological support may also be indicated. The evaluation of such programs is beyond the scope of this paper, however.
} 
concern is our finding that younger children are more negatively affected than older ones. To the extent that the accumulation of human capital is a building process, a child who falls behind in one year may fall further and further behind with subsequent years of education. Consequently, longer-term interventions may be indicated. ${ }^{27}$

Lengthy and frequent overseas deployments are now commonplace for members of the U.S. military and their families. Recent reports have emphasized how the intensity of current deployments have led to growing strains on the U.S. military—perhaps to a near "breaking point.” This study has aimed to provide firm evidence about one source of stress on military households: the extent to which a parent's deployment adversely affects a child's academic performance. Our estimates give policymakers a better understanding of the indirect costs of war and suggest ways to mitigate them. Clearly, much work remains to be done, but understanding the impacts of the Global War on Terror on the welfare of military families seems an important consideration for a nation committed to providing national security with an All-Volunteer Force.

\footnotetext{
${ }^{27}$ Apart from the direct relevance of these findings for educators in schools with children from military families, our paper also contributes to the broader literature on the effect of parental absences-such as temporary work assignments away from home or inter-city commuting —on a child's academic performance. Hiew (1992), for example, compares the effect of military and civilian parental absences in Japan and Canada on children's behavioral outcomes and finds comparable behavioral problems.
} 


\section{References}

Altonji, Joseph, Todd Elder, and Christopher Taber. 2000. "Selection on Observed and Unobserved Variables: Assessing the Effectiveness of Catholic Schools.” NBER Working Paper 7831. Cambridge, MA: National Bureau of Economic Research.

Angrist, Josh, and John Johnson. 2000. "Effects of Work-related Absences on Families: Evidence from the Gulf War.” Industrial and Labor Relations Review 54(1): 41-58.

Baker, Peter, Michael A. Fletcher, and Michael Abramowitz. 2006. "Twenty-Five Minutes in the Oval Office: President Bush on Iraq, Elections, and Immigration." Washington Post, December 20, 2006, page A16. (Accessed on-line: http://www.washingtonpost.com/wpdyn/content/article/2006/12/19/AR2006121900886.html.)

Benjamin, Mark. 2005. “How Many Troops Have Gone to War?” Salon.com, April 12, 2005. http://dir.salon.com/story/news/feature/2005/04/12/troops_numbers/index.html

CTB/McGraw-Hill. 2000. "Terra Nova (The Second Edition): Frequently Asked Questions.” Monterey, CA: CTB/McGraw-Hill.

Defense Manpower Data Center. 2005. "March 2005 Status of Forces Survey of Active-Duty Members.” Washington: DMDC.

Hiew, C. 1992. Separated by Their Work: Families with Fathers Living Apart. Environment and Society 24, no. 2: 206-25

Jaffe, Greg. 2006. “Despite a \$168B Budget, Army Faces Cash Crunch.” Wall Street Journal, December 11.

Lyle, David S. 2006. "Using Military Deployments and Job Assignments to Estimate the Effect of Parental Absences and Household Relocations on Children's Academic Achievement." Journal of Labor Economics 24(2): 319-350.

Pisano, Mark Charles. 1992. "The Children of Operation Desert Storm: An Analysis of California Achievement Test Scores in Sixth Graders of Deployed and Nondeployed Parents." Ph.D. dissertation, Campbell University.

Ricks, Thomas E., and Ann Scott Tyson. 2006. "Abizaid Says Withdrawal Would Mean More Unrest." Washington Post, November 16, 2006, p. A22. (Accessed on-line:

http://www.washingtonpost.com/wpdyn/content/article/2006/11/15/AR2006111500800_pf.html.)

Schoomaker, Peter J., General. 2006. "Statement before the Commission on the National Guard and Reserves [December 14, 2006]." Washington: Commission on the National Guard and Reserves. (Accessed on-line: http://www.cngr.gov/public-hearings-events.asp) 
U.S. Department of Defense. 2005. Annual Report to the President and the Congress. Washington, DC: Office of the Executive Secretary, U.S. Department of Defense. (Accessed on-line: http://www.dod.mil/execsec/adr2005.pdf)

U.S. Department of Defense Education Activity. 2003. “DoDEA Facts: 2003.” Arlington, VA: Office of Communications, DoDEA. (Accessed on-line:

http://www.dodea.edu/communications/pdf/dodeafacts2003.pdf)

U.S. Department of Defense Education Activity. 2004. “Overview: 2004.” Arlington, VA: DoDEA. (Accessed on-line: http://www.dodea.edu/aar/2004/pdf/overview2004.pdf)

U.S. Department of Defense Education Activity. 2006. “TerraNova Scores for DoDEA 2005.” (Accessed on-line, 7 July 2006:

http://www.dodea.edu/data/sys_tn.cfm?dodaac=DODEA\&year=2005) 


\begin{tabular}{|c|c|c|c|c|c|c|c|c|c|}
\hline & \multirow{2}{*}{$\begin{array}{c}\text { A. Population } \\
\text { (1) }\end{array}$} & \multicolumn{2}{|c|}{$\begin{array}{l}\text { B. Ever Deployed in } \\
\text { the School Year }\end{array}$} & \multicolumn{2}{|c|}{$\begin{array}{l}\text { C. Months Deployed in } \\
\text { the School Year }\end{array}$} & \multicolumn{2}{|c|}{$\begin{array}{l}\text { D. Deployed at the } \\
\text { Time of the Exam }\end{array}$} & \multicolumn{2}{|c|}{$\begin{array}{l}\text { E. Months Deployed in } \\
\text { the Past Five Years }\end{array}$} \\
\hline & & $\begin{array}{l}\text { No } \\
(1)\end{array}$ & $\begin{array}{l}\text { Yes } \\
(2)\end{array}$ & $\begin{array}{l}1-3 \\
(1)\end{array}$ & $\begin{array}{l}4-8 \\
(2)\end{array}$ & $\begin{array}{l}\text { No } \\
(1)\end{array}$ & $\begin{array}{l}\text { Yes } \\
(2)\end{array}$ & $\begin{array}{l}1-8 \\
(1)\end{array}$ & $\begin{array}{l}9+ \\
(2)\end{array}$ \\
\hline $\begin{array}{c}\text { Total } \\
\text { NCE Score }\end{array}$ & $\begin{array}{c}57.07 \\
\{14.14\}\end{array}$ & $\begin{array}{c}57.04 \\
\{14.17\}\end{array}$ & $\begin{array}{c}57.15 \\
\{14.06\}\end{array}$ & $\begin{array}{c}57.17 \\
\{14.05\}\end{array}$ & $\begin{array}{c}57.13 \\
\{14.06\}\end{array}$ & $\begin{array}{c}57.16 \\
\{14.15\}\end{array}$ & $\begin{array}{c}56.63 \\
\{14.12\}\end{array}$ & $\begin{array}{c}57.06 \\
\{14.16\}\end{array}$ & $\begin{array}{c}56.99 \\
\{13.94\}\end{array}$ \\
\hline $\begin{array}{c}\text { Math } \\
\text { NCE Score }\end{array}$ & $\begin{array}{c}55.50 \\
\{15.99\}\end{array}$ & $\begin{array}{c}55.52 \\
\{16.00\}\end{array}$ & $\begin{array}{c}55.43 \\
\{15.96\}\end{array}$ & $\begin{array}{c}55.51 \\
\{15.95\}\end{array}$ & $\begin{array}{c}55.35 \\
\{15.98\}\end{array}$ & $\begin{array}{c}55.60 \\
\{15.99\}\end{array}$ & $\begin{array}{c}54.99 \\
\{15.97\}\end{array}$ & $\begin{array}{c}55.50 \\
\{15.95\}\end{array}$ & $\begin{array}{c}55.35 \\
\{15.91\}\end{array}$ \\
\hline $\begin{array}{l}\text { Science } \\
\text { NCE Score }\end{array}$ & $\begin{array}{c}54.90 \\
\{15.68\}\end{array}$ & $\begin{array}{c}54.83 \\
\{15.71\}\end{array}$ & $\begin{array}{c}55.10 \\
\{15.61\}\end{array}$ & $\begin{array}{c}55.06 \\
\{15.59\}\end{array}$ & $\begin{array}{c}55.16 \\
\{15.63\}\end{array}$ & $\begin{array}{c}54.95 \\
\{15.67\}\end{array}$ & $\begin{array}{c}54.65 \\
\{15.73\}\end{array}$ & $\begin{array}{c}54.91 \\
\{15.73\}\end{array}$ & $\begin{array}{c}55.26 \\
\{15.76\}\end{array}$ \\
\hline $\begin{array}{l}\text { Language Arts } \\
\text { NCE Score }\end{array}$ & $\begin{array}{c}57.37 \\
\{15.39\}\end{array}$ & $\begin{array}{c}57.35 \\
\{15.41\}\end{array}$ & $\begin{array}{c}57.44 \\
\{15.31\}\end{array}$ & $\begin{array}{c}57.46 \\
\{15.29\}\end{array}$ & $\begin{array}{c}57.43 \\
\{15.33\}\end{array}$ & $\begin{array}{c}57.45 \\
\{15.39\}\end{array}$ & $\begin{array}{c}56.96 \\
\{15.38\}\end{array}$ & $\begin{array}{c}57.35 \\
\{15.47\}\end{array}$ & $\begin{array}{c}57.29 \\
\{15.13\}\end{array}$ \\
\hline $\begin{array}{l}\text { Social Studies } \\
\text { NCE Score }\end{array}$ & $\begin{array}{c}55.86 \\
\{15.05\}\end{array}$ & $\begin{array}{c}55.78 \\
\{15.06\}\end{array}$ & $\begin{array}{c}56.09 \\
\{15.04\}\end{array}$ & $\begin{array}{c}56.07 \\
\{15.05\}\end{array}$ & $\begin{array}{c}56.12 \\
\{15.03\}\end{array}$ & $\begin{array}{c}55.90 \\
\{15.06\}\end{array}$ & $\begin{array}{c}55.66 \\
\{15.03\}\end{array}$ & $\begin{array}{c}55.81 \\
\{15.07\}\end{array}$ & $\begin{array}{c}56.05 \\
\{15.06\}\end{array}$ \\
\hline $\begin{array}{l}\text { Reading } \\
\text { NCE Score }\end{array}$ & $\begin{array}{c}56.78 \\
\{15.26\}\end{array}$ & $\begin{array}{c}56.70 \\
\{15.29\}\end{array}$ & $\begin{array}{c}56.98 \\
\{15.17\}\end{array}$ & $\begin{array}{c}56.92 \\
\{15.22\}\end{array}$ & $\begin{array}{c}57.05 \\
\{15.12\}\end{array}$ & $\begin{array}{c}56.85 \\
\{15.27\}\end{array}$ & $\begin{array}{c}56.39 \\
\{15.21\}\end{array}$ & $\begin{array}{c}56.76 \\
\{15.36\}\end{array}$ & $\begin{array}{c}56.77 \\
\{15.08\}\end{array}$ \\
\hline $\begin{array}{l}\text { Male } \\
\text { Child }\end{array}$ & $\begin{array}{c}0.49 \\
\{0.50\}\end{array}$ & $\begin{array}{c}0.49 \\
\{0.50\}\end{array}$ & $\begin{array}{c}0.49 \\
\{0.50\}\end{array}$ & $\begin{array}{c}0.49 \\
\{0.50\}\end{array}$ & $\begin{array}{c}0.49 \\
\{0.50\}\end{array}$ & $\begin{array}{c}0.49 \\
\{0.50\}\end{array}$ & $\begin{array}{c}0.49 \\
\{0.50\}\end{array}$ & $\begin{array}{c}0.49 \\
\{0.50\}\end{array}$ & $\begin{array}{c}0.49 \\
\{0.50\}\end{array}$ \\
\hline $\begin{array}{l}\text { White } \\
\text { Child }\end{array}$ & $\begin{array}{c}0.37 \\
\{0.48\}\end{array}$ & $\begin{array}{c}0.36 \\
\{0.48\}\end{array}$ & $\begin{array}{c}0.41 \\
\{0.49\}\end{array}$ & $\begin{array}{c}0.42 \\
\{0.49\}\end{array}$ & $\begin{array}{c}0.41 \\
\{0.49\}\end{array}$ & $\begin{array}{c}0.37 \\
\{0.48\}\end{array}$ & $\begin{array}{c}0.40 \\
\{0.49\}\end{array}$ & $\begin{array}{c}0.40 \\
\{0.49\}\end{array}$ & $\begin{array}{c}0.41 \\
\{0.49\}\end{array}$ \\
\hline $\begin{array}{l}\text { Black } \\
\text { Child }\end{array}$ & $\begin{array}{c}0.32 \\
\{0.47\}\end{array}$ & $\begin{array}{c}0.34 \\
\{0.47\}\end{array}$ & $\begin{array}{c}0.28 \\
\{0.45\}\end{array}$ & $\begin{array}{c}0.29 \\
\{0.45\}\end{array}$ & $\begin{array}{c}0.28 \\
\{0.45\}\end{array}$ & $\begin{array}{c}0.33 \\
\{0.47\}\end{array}$ & $\begin{array}{c}0.30 \\
\{0.46\}\end{array}$ & $\begin{array}{c}0.30 \\
\{0.46\}\end{array}$ & $\begin{array}{c}0.28 \\
\{0.45\}\end{array}$ \\
\hline $\begin{array}{l}\text { Parents } \\
\text { Married }\end{array}$ & $\begin{array}{c}0.92 \\
\{0.27\}\end{array}$ & $\begin{array}{c}0.92 \\
\{0.28\}\end{array}$ & $\begin{array}{c}0.94 \\
\{0.24\}\end{array}$ & $\begin{array}{c}0.94 \\
\{0.23\}\end{array}$ & $\begin{array}{c}0.93 \\
\{0.25\}\end{array}$ & $\begin{array}{c}0.92 \\
\{0.27\}\end{array}$ & $\begin{array}{c}0.94 \\
\{0.24\}\end{array}$ & $\begin{array}{c}0.93 \\
\{0.25\}\end{array}$ & $\begin{array}{c}0.93 \\
\{0.25\}\end{array}$ \\
\hline $\begin{array}{l}\text { Father is } \\
\text { in the Army }\end{array}$ & $\begin{array}{c}0.88 \\
\{0.32\}\end{array}$ & $\begin{array}{c}0.86 \\
\{0.35\}\end{array}$ & $\begin{array}{c}0.95 \\
\{0.22\}\end{array}$ & $\begin{array}{c}0.95 \\
\{0.22\}\end{array}$ & $\begin{array}{c}0.95 \\
\{0.22\}\end{array}$ & $\begin{array}{c}0.87 \\
\{0.34\}\end{array}$ & $\begin{array}{c}0.95 \\
\{0.22\}\end{array}$ & $\begin{array}{c}0.92 \\
\{0.27\}\end{array}$ & $\begin{array}{c}0.94 \\
\{0.23\}\end{array}$ \\
\hline $\begin{array}{l}\text { Parent is a High } \\
\text { School Graduate }\end{array}$ & $\begin{array}{c}0.71 \\
\{0.45\}\end{array}$ & $\begin{array}{c}0.71 \\
\{0.46\}\end{array}$ & $\begin{array}{c}0.74 \\
\{0.44\}\end{array}$ & $\begin{array}{c}0.73 \\
\{0.45\}\end{array}$ & $\begin{array}{c}0.75 \\
\{0.43\}\end{array}$ & $\begin{array}{c}0.71 \\
\{0.45\}\end{array}$ & $\begin{array}{c}0.74 \\
\{0.44\}\end{array}$ & $\begin{array}{c}0.73 \\
\{0.45\}\end{array}$ & $\begin{array}{c}0.75 \\
\{0.43\}\end{array}$ \\
\hline $\begin{array}{l}\text { Parent has } \\
\text { Some College }\end{array}$ & $\begin{array}{c}0.20 \\
\{0.40\}\end{array}$ & $\begin{array}{c}0.21 \\
\{0.41\}\end{array}$ & $\begin{array}{c}0.19 \\
\{0.39\}\end{array}$ & $\begin{array}{c}0.20 \\
\{0.40\}\end{array}$ & $\begin{array}{c}0.18 \\
\{0.38\}\end{array}$ & $\begin{array}{c}0.21 \\
\{0.41\}\end{array}$ & $\begin{array}{c}0.19 \\
\{0.39\}\end{array}$ & $\begin{array}{c}0.20 \\
\{0.40\}\end{array}$ & $\begin{array}{c}0.18 \\
\{0.38\}\end{array}$ \\
\hline $\begin{array}{c}\text { Parent is a } \\
\text { College Graduate }\end{array}$ & $\begin{array}{c}0.07 \\
\{0.25\}\end{array}$ & $\begin{array}{c}0.07 \\
\{0.25\}\end{array}$ & $\begin{array}{c}0.06 \\
\{0.24\}\end{array}$ & $\begin{array}{c}0.06 \\
\{0.24\}\end{array}$ & $\begin{array}{c}0.06 \\
\{0.24\}\end{array}$ & $\begin{array}{c}0.07 \\
\{0.25\}\end{array}$ & $\begin{array}{c}0.06 \\
\{0.23\}\end{array}$ & $\begin{array}{c}0.06 \\
\{0.24\}\end{array}$ & $\begin{array}{c}0.06 \\
\{0.23\}\end{array}$ \\
\hline $\begin{array}{c}\text { Parent has a } \\
\text { Graduate Degree }\end{array}$ & $\begin{array}{c}0.01 \\
\{0.09\}\end{array}$ & $\begin{array}{c}0.01 \\
\{0.10\}\end{array}$ & $\begin{array}{c}0.01 \\
\{0.08\}\end{array}$ & $\begin{array}{c}0.01 \\
\{0.08\}\end{array}$ & $\begin{array}{c}0.01 \\
\{0.07\}\end{array}$ & $\begin{array}{c}0.01 \\
\{0.10\}\end{array}$ & $\begin{array}{c}0.01 \\
\{0.07\}\end{array}$ & $\begin{array}{c}0.01 \\
\{0.09\}\end{array}$ & $\begin{array}{c}0.01 \\
\{0.07\}\end{array}$ \\
\hline $\begin{array}{l}\text { Parent AFQT } \\
\text { (Cat } 1 \text { \& 2) }\end{array}$ & $\begin{array}{c}0.31 \\
\{0.46\}\end{array}$ & $\begin{array}{c}0.31 \\
\{0.46\}\end{array}$ & $\begin{array}{c}0.32 \\
\{0.46\}\end{array}$ & $\begin{array}{c}0.32 \\
\{0.47\}\end{array}$ & $\begin{array}{c}0.31 \\
\{0.46\}\end{array}$ & $\begin{array}{c}0.31 \\
\{0.46\}\end{array}$ & $\begin{array}{c}0.30 \\
\{0.46\}\end{array}$ & $\begin{array}{c}0.32 \\
\{0.46\}\end{array}$ & $\begin{array}{c}0.31 \\
\{0.46\}\end{array}$ \\
\hline $\begin{array}{l}\text { Parent AFQT } \\
\text { (Cat 3A) }\end{array}$ & $\begin{array}{c}0.26 \\
\{0.44\}\end{array}$ & $\begin{array}{c}0.27 \\
\{0.44\}\end{array}$ & $\begin{array}{c}0.26 \\
\{0.44\}\end{array}$ & $\begin{array}{c}0.26 \\
\{0.44\}\end{array}$ & $\begin{array}{c}0.25 \\
\{0.44\}\end{array}$ & $\begin{array}{c}0.27 \\
\{0.44\}\end{array}$ & $\begin{array}{c}0.26 \\
\{0.44\}\end{array}$ & $\begin{array}{c}0.26 \\
\{0.44\}\end{array}$ & $\begin{array}{c}0.27 \\
\{0.44\}\end{array}$ \\
\hline $\begin{array}{l}\text { Parent AFQT } \\
\text { (Cat 3B) }\end{array}$ & $\begin{array}{c}0.36 \\
\{0.48\}\end{array}$ & $\begin{array}{c}0.36 \\
\{0.48\}\end{array}$ & $\begin{array}{c}0.36 \\
\{0.48\}\end{array}$ & $\begin{array}{c}0.35 \\
\{0.48\}\end{array}$ & $\begin{array}{c}0.37 \\
\{0.48\}\end{array}$ & $\begin{array}{c}0.35 \\
\{0.48\}\end{array}$ & $\begin{array}{c}0.37 \\
\{0.48\}\end{array}$ & $\begin{array}{c}0.36 \\
\{0.48\}\end{array}$ & $\begin{array}{c}0.36 \\
\{0.48\}\end{array}$ \\
\hline $\begin{array}{l}\text { Combat Arms } \\
\text { Branch }\end{array}$ & $\begin{array}{c}0.32 \\
\{0.47\}\end{array}$ & $\begin{array}{c}0.31 \\
\{0.46\}\end{array}$ & $\begin{array}{c}0.36 \\
\{0.48\}\end{array}$ & $\begin{array}{c}0.35 \\
\{0.48\}\end{array}$ & $\begin{array}{c}0.36 \\
\{0.48\}\end{array}$ & $\begin{array}{c}0.32 \\
\{0.46\}\end{array}$ & $\begin{array}{c}0.34 \\
\{0.47\}\end{array}$ & $\begin{array}{c}0.35 \\
\{0.48\}\end{array}$ & $\begin{array}{c}0.38 \\
\{0.49\}\end{array}$ \\
\hline $\begin{array}{c}\text { Combat Support } \\
\text { Branch }\end{array}$ & $\begin{array}{c}0.16 \\
\{0.47\}\end{array}$ & $\begin{array}{c}0.16 \\
\{0.37\}\end{array}$ & $\begin{array}{c}0.17 \\
\{0.37\}\end{array}$ & $\begin{array}{c}0.17 \\
\{0.38\}\end{array}$ & $\begin{array}{c}0.16 \\
\{0.37\}\end{array}$ & $\begin{array}{c}0.17 \\
\{0.37\}\end{array}$ & $\begin{array}{c}0.16 \\
\{0.37\}\end{array}$ & $\begin{array}{c}0.17 \\
\{0.37\}\end{array}$ & $\begin{array}{c}0.16 \\
\{0.37\}\end{array}$ \\
\hline $\begin{array}{l}\text { Combat Service } \\
\text { Support Branch }\end{array}$ & $\begin{array}{c}0.44 \\
\{0.50\}\end{array}$ & $\begin{array}{c}0.44 \\
\{0.50\}\end{array}$ & $\begin{array}{c}0.42 \\
\{0.49\}\end{array}$ & $\begin{array}{c}0.41 \\
\{0.49\}\end{array}$ & $\begin{array}{c}0.42 \\
\{0.49\}\end{array}$ & $\begin{array}{c}0.43 \\
\{0.50\}\end{array}$ & $\begin{array}{c}0.44 \\
\{0.50\}\end{array}$ & $\begin{array}{c}0.42 \\
\{0.49\}\end{array}$ & $\begin{array}{c}0.41 \\
\{0.49\}\end{array}$ \\
\hline Observations & 56,116 & 41,760 & 14,356 & 7,513 & 6,843 & 46,665 & 9,451 & 17,746 & 12,899 \\
\hline $\begin{array}{l}\text { Standard deviations } \\
\text { Education Activity (D } \\
\text { (West Point, NY). Ar } \\
\text { constructed using Ar } \\
\text { "past five years" are } \\
\text { "current school year" } \\
\text { learning disabilities, } \\
\text { a soldier receiving ho } \\
\text { hostile fire pay allowa } \\
\text { grouping above is ca }\end{array}$ & $\begin{array}{l}\text { pay data. The " } \\
\text { ined as five year } \\
\text { mple and the "la } \\
\text { sical disabilities, } \\
\text { le fire pay. The } \\
\text { e. The omitted } \\
\text { ory } 4 \text { and } 5 \text {. }\end{array}$ & back fron & sample incl & $\begin{array}{l}\text { exam. Th } \\
\text { de only mai }\end{array}$ & $\begin{array}{l}\text { st of the pre } \\
\text { are } 51,362 \\
\text { eam childre } \\
\text { ns, and Eng }\end{array}$ & $\begin{array}{l}\text { ious year } t \\
\text { bservation } \\
\text { I. Non-mai }\end{array}$ & $\begin{array}{l}\text { n the "pas } \\
\text { tream chil }\end{array}$ & $\begin{array}{l}\text { ence varia } \\
\text { the curren } \\
\text { ars" samp } \\
\text { lude childr } \\
\text { ployments }\end{array}$ & $\begin{array}{l}\text { e } \\
\text { aalysis } \\
\text { are } \\
\text { ar. The } \\
\text { 3oth the } \\
\text { vith } \\
\text { espond to } \\
\text { he monthly } \\
\text { AFQT }\end{array}$ \\
\hline
\end{tabular}


Table 2. Effect of a Parent's Deployment on Child's Total NCE Score during the Current School Year Dependent Variable: Child's Total NCE Score

\begin{tabular}{|c|c|c|c|c|c|c|c|c|}
\hline & \multicolumn{4}{|c|}{ A. Ever Deployed } & \multicolumn{4}{|c|}{ B. Months Deployed } \\
\hline & $\begin{array}{l}\text { OLS } \\
(1)\end{array}$ & $\begin{array}{l}\text { OLS } \\
(2)\end{array}$ & $\begin{array}{c}\text { OLS } \\
(3)\end{array}$ & $\begin{array}{l}2 S L S \\
(4)\end{array}$ & $\begin{array}{l}\text { OLS } \\
(1)\end{array}$ & $\begin{array}{l}\text { OLS } \\
(2)\end{array}$ & $\begin{array}{c}\text { OLS } \\
(3)\end{array}$ & $\begin{array}{l}\text { 2SLS } \\
(4)\end{array}$ \\
\hline Ever Deployed & $\begin{array}{l}-0.041 \\
(0.155)\end{array}$ & $\begin{array}{l}-0.450 \\
(0.168)\end{array}$ & $\begin{array}{l}-0.419 \\
(0.149)\end{array}$ & $\begin{array}{l}-0.557 \\
(0.235)\end{array}$ & & & & \\
\hline Months Deployed & & & & & $\begin{array}{l}-0.058 \\
(0.029)\end{array}$ & $\begin{array}{l}-0.130 \\
(0.029)\end{array}$ & $\begin{array}{l}-0.112 \\
(0.028)\end{array}$ & $\begin{array}{l}-0.136 \\
(0.033)\end{array}$ \\
\hline $\begin{array}{l}\text { Male } \\
\text { Child }\end{array}$ & & $\begin{array}{l}-2.046 \\
(0.165)\end{array}$ & $\begin{array}{l}-2.159 \\
(0.162)\end{array}$ & $\begin{array}{l}-2.159 \\
(0.162)\end{array}$ & & $\begin{array}{l}-2.046 \\
(0.165)\end{array}$ & $\begin{array}{l}-2.158 \\
(0.162)\end{array}$ & $\begin{array}{l}-2.158 \\
(0.162)\end{array}$ \\
\hline $\begin{array}{l}\text { Black } \\
\text { Child }\end{array}$ & & $\begin{array}{l}-7.028 \\
(0.194)\end{array}$ & $\begin{array}{l}-5.124 \\
(0.211)\end{array}$ & $\begin{array}{l}-5.128 \\
(0.211)\end{array}$ & & $\begin{array}{l}-7.032 \\
(0.194)\end{array}$ & $\begin{array}{l}-5.126 \\
(0.211)\end{array}$ & $\begin{array}{l}-5.129 \\
(0.211)\end{array}$ \\
\hline $\begin{array}{l}\text { Other Race } \\
\text { Child }\end{array}$ & & $\begin{array}{l}-1.856 \\
(0.197)\end{array}$ & $\begin{array}{l}-0.885 \\
(0.199)\end{array}$ & $\begin{array}{l}-0.887 \\
(0.199)\end{array}$ & & $\begin{array}{l}-1.854 \\
(0.197)\end{array}$ & $\begin{array}{l}-0.883 \\
(0.199)\end{array}$ & $\begin{array}{l}-0.884 \\
(0.199)\end{array}$ \\
\hline $\begin{array}{l}\text { Parents } \\
\text { Married }\end{array}$ & & & $\begin{array}{l}1.100 \\
(0.290)\end{array}$ & $\begin{array}{c}1.100 \\
(0.290)\end{array}$ & & & $\begin{array}{c}1.096 \\
(0.290)\end{array}$ & $\begin{array}{c}1.094 \\
(0.290)\end{array}$ \\
\hline $\begin{array}{l}\text { Father is } \\
\text { in the Army }\end{array}$ & & & $\begin{array}{l}1.176 \\
(0.271)\end{array}$ & $\begin{array}{c}1.196 \\
(0.272)\end{array}$ & & & $\begin{array}{c}1.183 \\
(0.271)\end{array}$ & $\begin{array}{l}1.198 \\
(0.271)\end{array}$ \\
\hline $\begin{array}{c}\text { Parent is a } \\
\text { High School Drop Out }\end{array}$ & & & $\begin{array}{l}0.380 \\
(0.872)\end{array}$ & $\begin{array}{c}0.389 \\
(0.873)\end{array}$ & & & $\begin{array}{c}0.385 \\
(0.872)\end{array}$ & $\begin{array}{r}0.393 \\
(0.873)\end{array}$ \\
\hline $\begin{array}{l}\text { Parent has } \\
\text { Some College }\end{array}$ & & & $\begin{array}{l}1.589 \\
(0.198)\end{array}$ & $\begin{array}{c}1.586 \\
(0.198)\end{array}$ & & & $\begin{array}{c}1.584 \\
(0.198)\end{array}$ & $\begin{array}{c}1.581 \\
(0.198)\end{array}$ \\
\hline $\begin{array}{l}\text { Parent has a } \\
\text { College Degree }\end{array}$ & & & $\begin{array}{c}3.627 \\
(0.333)\end{array}$ & $\begin{array}{c}3.623 \\
(0.333)\end{array}$ & & & $\begin{array}{c}3.621 \\
(0.333)\end{array}$ & $\begin{array}{l}3.617 \\
(0.333)\end{array}$ \\
\hline $\begin{array}{c}\text { Parent has a } \\
\text { Graduate Degree }\end{array}$ & & & $\begin{array}{c}4.692 \\
(0.871)\end{array}$ & $\begin{array}{c}4.682 \\
(0.870)\end{array}$ & & & $\begin{array}{c}4.677 \\
(0.871)\end{array}$ & $\begin{array}{l}4.666 \\
(0.870)\end{array}$ \\
\hline $\begin{array}{c}\text { Combat Support } \\
\text { Branch }\end{array}$ & & & $\begin{array}{l}-0.087 \\
(0.252)\end{array}$ & $\begin{array}{l}-0.088 \\
(0.252)\end{array}$ & & & $\begin{array}{l}-0.091 \\
(0.252)\end{array}$ & $\begin{array}{l}-0.093 \\
(0.252)\end{array}$ \\
\hline $\begin{array}{l}\text { Combat Service } \\
\text { Support Branch }\end{array}$ & & & $\begin{array}{l}-0.885 \\
(0.196)\end{array}$ & $\begin{array}{l}-0.886 \\
(0.196)\end{array}$ & & & $\begin{array}{l}-0.883 \\
(0.196)\end{array}$ & $\begin{array}{l}-0.883 \\
(0.196)\end{array}$ \\
\hline Special Branch & & & $\begin{array}{c}0.524 \\
(0.333)\end{array}$ & $\begin{array}{c}0.516 \\
(0.333)\end{array}$ & & & $\begin{array}{c}0.521 \\
(0.333)\end{array}$ & $\begin{array}{l}0.515 \\
(0.333)\end{array}$ \\
\hline $\begin{array}{l}\text { Parent AFQT } \\
\text { (Cat } 1 \text { \& 2) }\end{array}$ & & & $\begin{array}{l}2.946 \\
(0.221)\end{array}$ & $\begin{array}{c}2.946 \\
(0.221)\end{array}$ & & & $\begin{array}{c}2.946 \\
(0.221)\end{array}$ & $\begin{array}{r}2.946 \\
(0.221)\end{array}$ \\
\hline $\begin{array}{l}\text { Parent AFQT } \\
\text { (Cat 3B) }\end{array}$ & & & $\begin{array}{l}-1.356 \\
(0.210)\end{array}$ & $\begin{array}{l}-1.355 \\
(0.210)\end{array}$ & & & $\begin{array}{l}-1.353 \\
(0.210)\end{array}$ & $\begin{array}{l}-1.351 \\
(0.210)\end{array}$ \\
\hline $\begin{array}{l}\text { Parent AFQT } \\
\text { (Cat } 4 \text { \& Cat 5) }\end{array}$ & & & $\begin{array}{l}-2.457 \\
(0.353)\end{array}$ & $\begin{array}{l}-2.461 \\
(0.353)\end{array}$ & & & $\begin{array}{l}-2.459 \\
(0.353)\end{array}$ & $\begin{array}{l}-2.462 \\
(0.353)\end{array}$ \\
\hline $\begin{array}{c}\text { Combat } \\
\text { Support Branch }\end{array}$ & & & $\begin{array}{l}-0.087 \\
(0.252)\end{array}$ & $\begin{array}{l}-0.088 \\
(0.252)\end{array}$ & & & $\begin{array}{l}-0.091 \\
(0.252)\end{array}$ & $\begin{array}{l}-0.093 \\
(0.252)\end{array}$ \\
\hline $\begin{array}{l}\text { Combat Service } \\
\text { Support Branch }\end{array}$ & & & $\begin{array}{l}-0.885 \\
(0.196)\end{array}$ & $\begin{array}{l}-0.886 \\
(0.196)\end{array}$ & & & $\begin{array}{l}-0.883 \\
(0.196)\end{array}$ & $\begin{array}{l}-0.883 \\
(0.196)\end{array}$ \\
\hline $\begin{array}{l}\text { Special } \\
\text { Branch }\end{array}$ & & & $\begin{array}{l}0.524 \\
(0.333)\end{array}$ & $\begin{array}{c}0.516 \\
(0.333)\end{array}$ & & & $\begin{array}{c}0.521 \\
(0.333)\end{array}$ & $\begin{array}{r}0.515 \\
(0.333)\end{array}$ \\
\hline 1st Stage & & & & $\begin{array}{c}0.698 \\
(0.004)\end{array}$ & & & & $\begin{array}{c}1.024 \\
(0.004)\end{array}$ \\
\hline $\mathrm{R}^{2}$ & 0.01 & 0.06 & 0.09 & 0.28 & 0.01 & 0.06 & 0.09 & 0.63 \\
\hline Observations & 56,116 & 56,116 & 56,116 & 56,116 & 56,116 & 56,116 & 56,116 & 56,116 \\
\hline
\end{tabular}

Standard errors (in parenthesis) account for clustering at the individual child level because some children appear in multiple years. All regressions contain a constant and dummies for the year of exam and for grade levels 4 through 11. Race dummies control for white, black, and other race. Education dummies control for high school dropout, high school graduate, some college, college degree, and graduate degree. AFQT dummies controls for the five primary AFQT groups. Occupational dummies control for combat arms, combat support, combat service support, and special branch. The two instruments used in the 2SLS estimation are constructed from the unit of assignment (see main text for details). Hausman test statistics have the following p-values: panel A - (3),(4)=1.000; panel B -

(3),(4)=1.000. The omitted race is white, the omitted education level is high school graduate, the omitted occupational group is combat arms, and the omitted AFQT group is cat 3A. Clustering standard errors at the unit level for 2SLS regressions does not change the statistical significance of estimates. See notes in Table 1 for additional sample description. 
A. Deployments in the Current School Year

\begin{tabular}{cccccc}
\hline Math & Science & $\begin{array}{c}\text { Language } \\
\text { Arts }\end{array}$ & $\begin{array}{c}\text { Social } \\
\text { Studies }\end{array}$ & Reading & Total \\
$(1)$ & $(2)$ & $(3)$ & $(4)$ & $(5)$ & $(6)$ \\
$\mathbf{- 0 . 7 5 5}$ & $\mathbf{- 0 . 7 2 3}$ & $\mathbf{- 0 . 3 3 8}$ & -0.266 & -0.127 & $\mathbf{- 0 . 4 1 9}$ \\
$\mathbf{( 0 . 1 7 0 )}$ & $\mathbf{( 0 . 1 6 3 )}$ & $\mathbf{( 0 . 1 6 1 )}$ & $(0.160)$ & $(0.159)$ & $\mathbf{( 0 . 1 4 9 )}$
\end{tabular}

Ever Deployed in Current School Year

$(0.170)$

B. Deployment Duration in the Current School Year

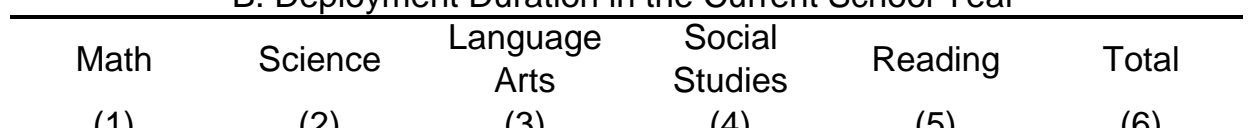

(1)

(2)

(3)

(4)

(5)

Months Deployed during Current School Year

$-0.188$

$-0.169$

$-0.090$

$-0.074$

$-0.042$

$-0.112$

$(0.032)$

(0.031)

(0.030)

$(0.030)$

(0.028)

C. Deployed during the Month of the Exam

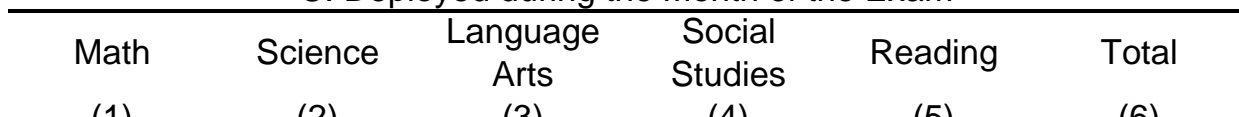

(1)

(2)

(3)

(4)

(5)

Deployed In March

-0.921
$(0.177)$

$-0.813$

$-0.679$

$-0.519$

$-0.594$

$-0.747$

(0.172)

(0.169)

$(0.167)$

$(0.167)$

(0.155)

D. Timing of Deployment in the Current School Year

\begin{tabular}{cccccc}
\multicolumn{5}{c}{ D. Timing of Deployment in the Current School Year } \\
\hline Math & Science & $\begin{array}{c}\text { Language } \\
\text { Arts }\end{array}$ & $\begin{array}{c}\text { Social } \\
\text { Studies }\end{array}$ & Reading & Total
\end{tabular}

(3)

(4)

(5)

\section{Deployment Ending: \\ August - October}

$-0.143$

$-0.468$

0.034

$-0.280$

$-0.267$

$-0.122$

(0.398)

(0.392)

(0.379)

(0.384)

(0.378)

(0.349)

Deployment Ending:

$-0.786$

$-0.663$

0.033

0.010

0.316

$-0.170$

November - January

(0.322)

(0.303)

(0.299)

(0.301)

(0.293)

(0.275)

Deployment Ending in

$-0.800$

$-0.725$

$-0.362$

$-0.308$

$-0.252$

$-0.488$

February or Deployed in March

(0.181)

(0.174)

(0.172)

$(0.170)$

(0.171)

$(0.160)$

Observations

56,116

56,116

56,116

56,116

56,116

56,116

Standard errors (in parenthesis) account for clustering at the individual child level because some children appear in multiple years. All regressions are estimated by OLS and contain a constant and dummies for the year of exam and for grade levels 4 through 11. The full set of child and parental controls are presented in Table 2. See notes in Table 1 for additional sample description. 


\begin{tabular}{|c|c|c|c|c|c|c|}
\hline & (1) & (2) & (3) & (4) & (5) & (6) \\
\hline \multirow[t]{3}{*}{$\begin{array}{l}\text { Ever Deployed } \\
\text { in the Last } 5 \text { Years }\end{array}$} & $\begin{array}{l}-0.991 \\
(0.178)\end{array}$ & $\begin{array}{l}-0.790 \\
(0.166)\end{array}$ & $\begin{array}{l}-0.694 \\
(0.169)\end{array}$ & $\begin{array}{l}-0.614 \\
(0.164)\end{array}$ & $\begin{array}{l}-0.590 \\
(0.164)\end{array}$ & $\begin{array}{l}-0.784 \\
(0.158)\end{array}$ \\
\hline & \multicolumn{6}{|c|}{ B. Deployment Duration in the Past Five Years } \\
\hline & $\begin{array}{l}\text { Math } \\
\text { (1) }\end{array}$ & $\begin{array}{c}\text { Science } \\
\text { (2) }\end{array}$ & $\begin{array}{c}\text { Language } \\
\text { Arts } \\
\text { (3) }\end{array}$ & $\begin{array}{l}\text { Social } \\
\text { Studies } \\
(4)\end{array}$ & $\begin{array}{l}\text { Reading } \\
\text { (5) }\end{array}$ & $\begin{array}{l}\text { Total } \\
(6)\end{array}$ \\
\hline \multirow[t]{3}{*}{$\begin{array}{l}\text { Months Deployed } \\
\text { in the Last } 5 \text { Years }\end{array}$} & $\begin{array}{l}-0.085 \\
(0.016)\end{array}$ & $\begin{array}{l}-0.067 \\
(0.015)\end{array}$ & $\begin{array}{l}-0.066 \\
(0.015)\end{array}$ & $\begin{array}{l}-0.047 \\
(0.015)\end{array}$ & $\begin{array}{l}-0.045 \\
(0.015)\end{array}$ & $\begin{array}{l}-0.067 \\
(0.014)\end{array}$ \\
\hline & \multicolumn{6}{|c|}{ C. Timing of Last Deployment in the Past Five Years } \\
\hline & $\begin{array}{l}\text { Math } \\
(1)\end{array}$ & $\begin{array}{c}\text { Science } \\
\text { (2) }\end{array}$ & $\begin{array}{c}\text { Language } \\
\text { Arts } \\
\text { (3) }\end{array}$ & $\begin{array}{c}\text { Social } \\
\text { Studies } \\
(4)\end{array}$ & $\begin{array}{c}\text { Reading } \\
\text { (5) }\end{array}$ & $\begin{array}{l}\text { Total } \\
(6)\end{array}$ \\
\hline $\begin{array}{l}\text { Last Deployment Ending } \\
0 \text { - } 1 \text { Years Ago }\end{array}$ & $\begin{array}{l}-1.054 \\
(0.196)\end{array}$ & $\begin{array}{l}-0.844 \\
(0.185)\end{array}$ & $\begin{array}{l}-0.679 \\
(0.186)\end{array}$ & $\begin{array}{l}-0.550 \\
(0.182)\end{array}$ & $\begin{array}{l}-0.496 \\
(0.182)\end{array}$ & $\begin{array}{l}-0.768 \\
(0.174)\end{array}$ \\
\hline $\begin{array}{l}\text { Last Deployment Ending } \\
1 \text { - } 2 \text { Years Ago }\end{array}$ & $\begin{array}{l}-1.106 \\
(0.293)\end{array}$ & $\begin{array}{l}-1.024 \\
(0.278)\end{array}$ & $\begin{array}{l}-1.071 \\
(0.277)\end{array}$ & $\begin{array}{l}-0.891 \\
(0.277)\end{array}$ & $\begin{array}{l}-0.895 \\
(0.274)\end{array}$ & $\begin{array}{l}-1.040 \\
(0.256)\end{array}$ \\
\hline $\begin{array}{l}\text { Last Deployment Ending } \\
\qquad 2 \text { - } 3 \text { Years Ago }\end{array}$ & $\begin{array}{l}-0.880 \\
(0.344)\end{array}$ & $\begin{array}{l}-0.552 \\
(0.326)\end{array}$ & $\begin{array}{l}-0.584 \\
(0.335)\end{array}$ & $\begin{array}{l}-0.757 \\
(0.320)\end{array}$ & $\begin{array}{l}-0.671 \\
(0.328)\end{array}$ & $\begin{array}{l}-0.741 \\
(0.307)\end{array}$ \\
\hline $\begin{array}{l}\text { Last Deployment Ending } \\
3 \text { - } 4 \text { Years Ago }\end{array}$ & $\begin{array}{l}-0.910 \\
(0.362)\end{array}$ & $\begin{array}{l}-0.789 \\
(0.355)\end{array}$ & $\begin{array}{l}-0.794 \\
(0.346)\end{array}$ & $\begin{array}{l}-0.635 \\
(0.341)\end{array}$ & $\begin{array}{l}-0.629 \\
(0.341)\end{array}$ & $\begin{array}{l}-0.823 \\
(0.316)\end{array}$ \\
\hline $\begin{array}{l}\text { Last Deployment Ending } \\
\qquad 4 \text { - } 5 \text { Years Ago }\end{array}$ & $\begin{array}{l}-0.407 \\
(0.396)\end{array}$ & $\begin{array}{l}-0.155 \\
(0.387)\end{array}$ & $\begin{array}{l}-0.070 \\
(0.380)\end{array}$ & $\begin{array}{l}-0.375 \\
(0.376)\end{array}$ & $\begin{array}{l}-0.653 \\
(0.370)\end{array}$ & $\begin{array}{l}-0.400 \\
(0.343)\end{array}$ \\
\hline Observations & 51,362 & 51,362 & 51,362 & 51,362 & 51,362 & 51,362 \\
\hline
\end{tabular}

Standard errors (in parenthesis) account for clustering at the individual child level because some children appear in multiple years. All regressions are estimated by OLS and contain a constant and dummies for the year of exam and for grade levels 4 through 11 . The full set of child and parental controls are presented in Table 2. See notes in Table 1 for additional sample description. 
Table 5. Deployment Effects by Child Demographic Group Dependent Variable: Child's Total NCE Score

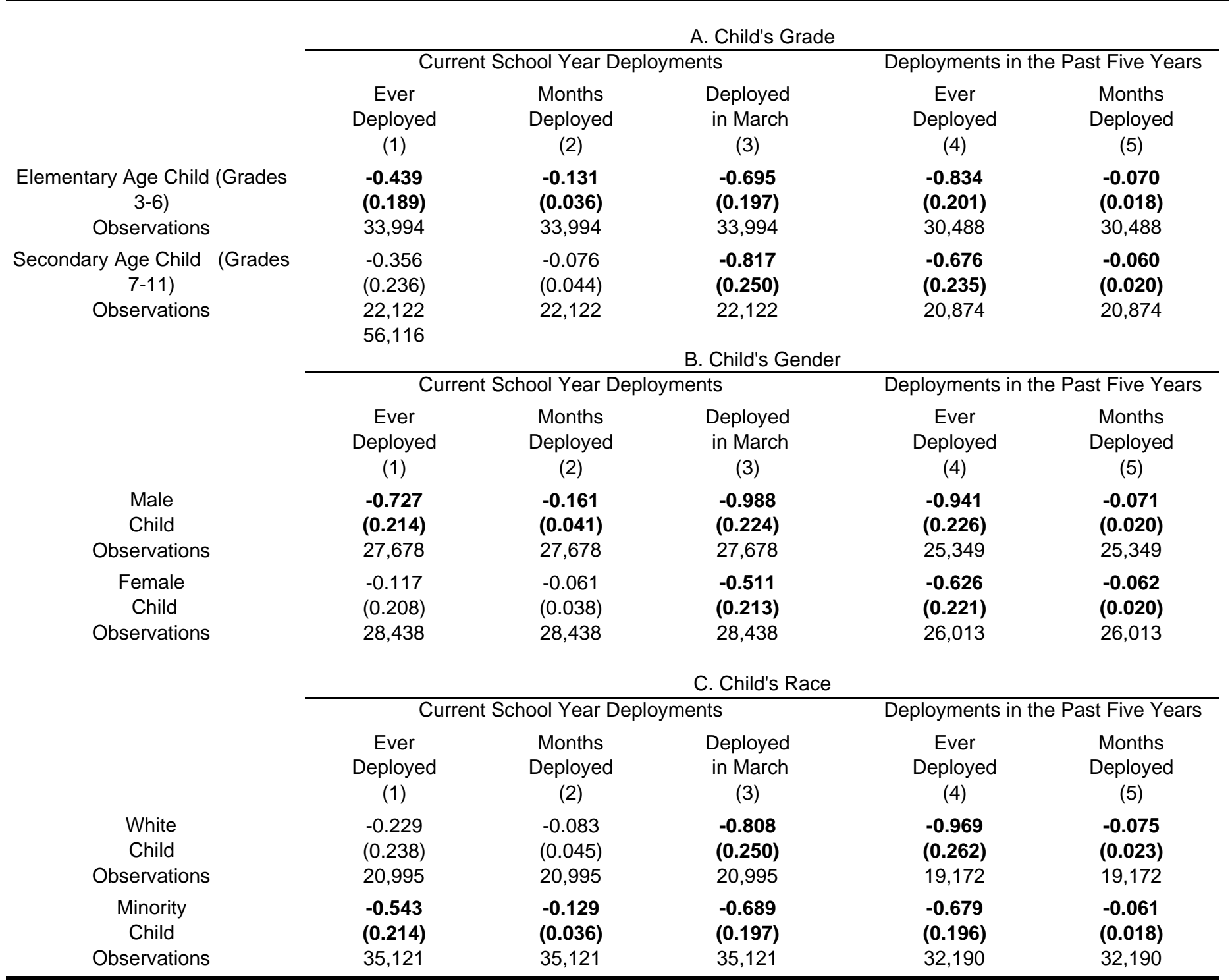

Standard errors (in parenthesis) account for clustering at the individual child level because some children appear in multiple years. All regressions are estimated by OLS and contain a constant and dummies for the year of exam and for grade levels 4 through 11 . The full set of child and parental controls are presented in Table 2. See notes in Table 1 for additional sample description. 
Table 6. Deployment Effects by Parental Demographic Group Dependent Variable: Child's Total NCE Score

\begin{tabular}{|c|c|c|c|c|c|}
\hline & \multicolumn{5}{|c|}{ A. Parent's Gender } \\
\hline & \multicolumn{3}{|c|}{ Current School Year Deployments } & \multicolumn{2}{|c|}{ Deployments in the Past Five Years } \\
\hline & $\begin{array}{c}\text { Ever } \\
\text { Deployed } \\
(1)\end{array}$ & $\begin{array}{l}\text { Months } \\
\text { Deployed } \\
\text { (2) }\end{array}$ & $\begin{array}{c}\text { Deployed } \\
\text { in March } \\
(3)\end{array}$ & $\begin{array}{c}\text { Ever } \\
\text { Deployed } \\
(4)\end{array}$ & $\begin{array}{l}\text { Months } \\
\text { Deployed } \\
\text { (5) }\end{array}$ \\
\hline $\begin{array}{c}\text { Father is } \\
\text { in the Army } \\
\text { Observations }\end{array}$ & $\begin{array}{l}-0.441 \\
(0.155) \\
49,453\end{array}$ & $\begin{array}{c}-0.118 \\
(0.029) \\
49,453\end{array}$ & $\begin{array}{c}-0.781 \\
(0.159) \\
49,453\end{array}$ & $\begin{array}{c}-0.790 \\
(0.168) \\
45,919\end{array}$ & $\begin{array}{l}-0.070 \\
(0.015) \\
45,919\end{array}$ \\
\hline $\begin{array}{c}\text { Mother is } \\
\text { in the Army } \\
\text { Observations }\end{array}$ & $\begin{array}{c}0.285 \\
(0.585) \\
6,663\end{array}$ & $\begin{array}{c}0.092 \\
(0.122) \\
6,663\end{array}$ & $\begin{array}{c}0.203 \\
(0.657) \\
6,663\end{array}$ & $\begin{array}{c}-0.526 \\
(0.472) \\
5,443\end{array}$ & $\begin{array}{c}0.005 \\
(0.049) \\
5,443\end{array}$ \\
\hline \multirow{3}{*}{ Observations } & \multicolumn{5}{|c|}{ B. Parent's Marital Status } \\
\hline & \multicolumn{3}{|c|}{ Current School Year Deployments } & \multicolumn{2}{|c|}{ Deployments in the Past Five Years } \\
\hline & $\begin{array}{c}\text { Ever } \\
\text { Deployed } \\
(1)\end{array}$ & $\begin{array}{c}\text { Months } \\
\text { Deployed } \\
(2)\end{array}$ & $\begin{array}{c}\text { Deployed } \\
\text { in March } \\
(3)\end{array}$ & $\begin{array}{c}\text { Ever } \\
\text { Deployed } \\
(4)\end{array}$ & $\begin{array}{l}\text { Months } \\
\text { Deployed } \\
\text { (5) }\end{array}$ \\
\hline $\begin{array}{c}\text { Parent } \\
\text { is Married } \\
\text { Observations }\end{array}$ & $\begin{array}{l}-0.432 \\
(0.154) \\
51,706\end{array}$ & $\begin{array}{l}-\mathbf{0 . 1 1 1} \\
(\mathbf{0 . 0 2 9 )} \\
51,706\end{array}$ & $\begin{array}{c}-0.806 \\
(\mathbf{0 . 1 5 9 )} \\
51,706\end{array}$ & $\begin{array}{l}-0.824 \\
(0.163) \\
47,682\end{array}$ & $\begin{array}{l}-0.069 \\
(0.015) \\
47,682\end{array}$ \\
\hline $\begin{array}{c}\text { Parent } \\
\text { is Single } \\
\text { Observations }\end{array}$ & $\begin{array}{c}0.000 \\
(0.588) \\
4,410\end{array}$ & $\begin{array}{c}-0.069 \\
(0.109) \\
4,410\end{array}$ & $\begin{array}{c}0.401 \\
(0.631) \\
4,410\end{array}$ & $\begin{array}{c}-0.085 \\
(0.563) \\
3,680\end{array}$ & $\begin{array}{c}-0.021 \\
(0.048) \\
3,680\end{array}$ \\
\hline \multirow{3}{*}{ Observations } & \multicolumn{5}{|c|}{ C. Parent's AFQT Score } \\
\hline & \multicolumn{3}{|c|}{ Current School Year Deployments } & \multicolumn{2}{|c|}{ Deployments in the Past Five Years } \\
\hline & $\begin{array}{c}\text { Ever } \\
\text { Deployed } \\
(1)\end{array}$ & $\begin{array}{c}\text { Months } \\
\text { Deployed } \\
(2)\end{array}$ & $\begin{array}{c}\text { Deployed } \\
\text { in March } \\
(3)\end{array}$ & $\begin{array}{c}\text { Ever } \\
\text { Deployed } \\
(4)\end{array}$ & $\begin{array}{l}\text { Months } \\
\text { Deployed } \\
\text { (5) }\end{array}$ \\
\hline $\begin{array}{l}\text { Parent in Cat } 2 \\
\text { or Above of AFQT } \\
\text { Observations }\end{array}$ & $\begin{array}{l}-0.176 \\
(0.273) \\
17,337\end{array}$ & $\begin{array}{l}-0.089 \\
(0.052) \\
17,337\end{array}$ & $\begin{array}{l}-0.937 \\
(0.294) \\
17,337\end{array}$ & $\begin{array}{l}-0.509 \\
(0.298) \\
15,884\end{array}$ & $\begin{array}{l}-0.032 \\
(0.025) \\
15,884\end{array}$ \\
\hline $\begin{array}{l}\text { Parent in Cat 3A } \\
\text { or Below of AFQT } \\
\text { Observations }\end{array}$ & $\begin{array}{l}-0.557 \\
(0.178) \\
38,779\end{array}$ & $\begin{array}{l}-0.122 \\
(0.033) \\
38,779\end{array}$ & $\begin{array}{l}-0.680 \\
(0.181) \\
38,779\end{array}$ & $\begin{array}{l}-0.923 \\
(0.186) \\
35,478\end{array}$ & $\begin{array}{l}-0.085 \\
(0.017) \\
35,478\end{array}$ \\
\hline \multirow{3}{*}{ Observations } & \multicolumn{5}{|c|}{ D. Parent's Civilian Education Level } \\
\hline & \multicolumn{3}{|c|}{ Current School Year Deployments } & \multicolumn{2}{|c|}{ Deployments in the Past Five Years } \\
\hline & $\begin{array}{l}\text { Ever } \\
\text { Deployed } \\
\quad(1)\end{array}$ & $\begin{array}{l}\text { Months } \\
\text { Deployed } \\
\text { (2) }\end{array}$ & $\begin{array}{l}\text { Deployed } \\
\text { in March } \\
\text { (3) }\end{array}$ & $\begin{array}{l}\text { Ever } \\
\text { Deployed } \\
\text { (4) }\end{array}$ & $\begin{array}{l}\text { Months } \\
\text { Deployed } \\
\text { (5) }\end{array}$ \\
\hline Parent with High School & -0.445 & -0.124 & -0.802 & -0.844 & -0.077 \\
\hline $\begin{array}{c}\text { Degree or Below } \\
\text { Observations }\end{array}$ & $\begin{array}{l}\mathbf{( 0 . 1 7 1 )} \\
40,451\end{array}$ & $\begin{array}{l}\mathbf{( 0 . 0 3 2 )} \\
40,451\end{array}$ & $\begin{array}{l}\mathbf{( 0 . 1 7 8 )} \\
40,451\end{array}$ & $\begin{array}{l}\mathbf{( 0 . 1 8 7 )} \\
36,135\end{array}$ & $\begin{array}{l}\mathbf{( 0 . 0 1 6 )} \\
36,135\end{array}$ \\
\hline $\begin{array}{c}\text { Parent with Some College or } \\
\text { Above } \\
\text { Observations }\end{array}$ & $\begin{array}{l}-0.307 \\
(0.297) \\
15,665\end{array}$ & $\begin{array}{l}-0.061 \\
(0.058) \\
15,665\end{array}$ & $\begin{array}{c}-0.557 \\
(0.309) \\
15,665\end{array}$ & $\begin{array}{c}-0.612 \\
(0.285) \\
15,227\end{array}$ & $\begin{array}{c}-0.041 \\
(0.027) \\
15,227\end{array}$ \\
\hline
\end{tabular}

Standard errors (in parenthesis) account for clustering at the individual child level because some children appear in multiple years. All regressions are estimated by OLS and contain a constant and dummies for the year of exam and for grade levels 4 through 11 . The full set of child and parental controls are presented in Table 2 . See notes in Table 1 for additional sample description. 


\begin{tabular}{|c|c|c|}
\hline & $\begin{array}{l}\text { A. DoDEA-Army } \\
\text { Sample }\end{array}$ & $\begin{array}{l}\text { B. Army } \\
\text { Population }\end{array}$ \\
\hline $\begin{array}{l}\text { Male } \\
\text { Child }\end{array}$ & $\begin{array}{c}0.51 \\
\{0.50\}\end{array}$ & $\begin{array}{c}0.51 \\
\{0.50\}\end{array}$ \\
\hline $\begin{array}{c}\text { Parent is an } \\
\text { E1 - E4 }\end{array}$ & $\begin{array}{c}0.10 \\
\{0.29\}\end{array}$ & $\begin{array}{c}0.12 \\
\{0.33\}\end{array}$ \\
\hline $\begin{array}{c}\text { Parent is an } \\
\text { E5 }\end{array}$ & $\begin{array}{c}0.19 \\
\{0.39\}\end{array}$ & $\begin{array}{c}0.19 \\
\{0.39\}\end{array}$ \\
\hline $\begin{array}{l}\text { Parent is an } \\
\text { E6 }\end{array}$ & $\begin{array}{c}0.32 \\
\{0.46\}\end{array}$ & $\begin{array}{c}0.31 \\
\{0.46\}\end{array}$ \\
\hline $\begin{array}{c}\text { Parent is an } \\
\text { E7 -E9 }\end{array}$ & $\begin{array}{c}0.40 \\
\{0.49\}\end{array}$ & $\begin{array}{c}0.38 \\
\{0.49\}\end{array}$ \\
\hline $\begin{array}{l}\text { White } \\
\text { Parent }\end{array}$ & $\begin{array}{c}0.46 \\
\{0.50\}\end{array}$ & $\begin{array}{c}0.46 \\
\{0.50\}\end{array}$ \\
\hline $\begin{array}{l}\text { Black } \\
\text { Parent }\end{array}$ & $\begin{array}{c}0.39 \\
\{0.49\}\end{array}$ & $\begin{array}{c}0.38 \\
\{0.48\}\end{array}$ \\
\hline $\begin{array}{l}\text { Other Race } \\
\text { Parent }\end{array}$ & $\begin{array}{c}0.15 \\
\{0.35\}\end{array}$ & $\begin{array}{c}0.17 \\
\{0.37\}\end{array}$ \\
\hline $\begin{array}{l}\text { Father is } \\
\text { in the Army }\end{array}$ & $\begin{array}{c}0.88 \\
\{0.32\}\end{array}$ & $\begin{array}{c}0.88 \\
\{0.33\}\end{array}$ \\
\hline $\begin{array}{l}\text { Parents } \\
\text { Married }\end{array}$ & $\begin{array}{c}0.92 \\
\{0.27\}\end{array}$ & $\begin{array}{c}0.86 \\
\{0.34\}\end{array}$ \\
\hline $\begin{array}{l}\text { Parent is a High } \\
\text { School Dropout }\end{array}$ & $\begin{array}{c}0.01 \\
\{0.08\}\end{array}$ & $\begin{array}{c}0.01 \\
\{0.08\}\end{array}$ \\
\hline $\begin{array}{l}\text { Parent is a High } \\
\text { School Graduate }\end{array}$ & $\begin{array}{c}0.72 \\
\{0.45\}\end{array}$ & $\begin{array}{c}0.74 \\
\{0.44\}\end{array}$ \\
\hline $\begin{array}{l}\text { Parent has } \\
\text { Some College }\end{array}$ & $\begin{array}{c}0.20 \\
\{0.40\}\end{array}$ & $\begin{array}{c}0.19 \\
\{0.39\}\end{array}$ \\
\hline $\begin{array}{l}\text { Parent is a } \\
\text { College Graduate }\end{array}$ & $\begin{array}{c}0.06 \\
\{0.25\}\end{array}$ & $\begin{array}{c}0.06 \\
\{0.24\}\end{array}$ \\
\hline $\begin{array}{c}\text { Parent has a } \\
\text { Graduate Degree }\end{array}$ & $\begin{array}{c}0.01 \\
\{0.09\}\end{array}$ & $\begin{array}{c}0.01 \\
\{0.09\}\end{array}$ \\
\hline $\begin{array}{l}\text { Parent AFQT } \\
\text { (Cat } 1 \text { \& Cat 2) }\end{array}$ & $\begin{array}{c}0.30 \\
\{0.46\}\end{array}$ & $\begin{array}{c}0.32 \\
\{0.47\}\end{array}$ \\
\hline $\begin{array}{c}\text { Parent AFQT } \\
(\text { Cat } 3 \mathrm{~A})\end{array}$ & $\begin{array}{c}0.26 \\
\{0.44\}\end{array}$ & $\begin{array}{c}0.26 \\
\{0.44\}\end{array}$ \\
\hline $\begin{array}{c}\text { Parent AFQT } \\
\quad \text { (Cat 3B) }\end{array}$ & $\begin{array}{c}0.36 \\
\{0.48\}\end{array}$ & $\begin{array}{c}0.35 \\
\{0.48\}\end{array}$ \\
\hline $\begin{array}{c}\text { Parent AFQT } \\
\text { (Cat } 4 \text { \& Cat 5) }\end{array}$ & $\begin{array}{c}0.07 \\
\{0.26\}\end{array}$ & $\begin{array}{c}0.07 \\
\{0.25\}\end{array}$ \\
\hline Observations & 62,165 & 371,736 \\
\hline
\end{tabular}

Standard deviations are in brackets. For DoDEA-Army sample, Army personnel data were merged with DoDEA records of individual children's Terra Nova test scores, using the child's social security number. The DoDEA-Army sample contains both non-mainstream and mainstream children. The Army population includes all Army enlisted personnel with dependents age 8 through age 17. 
Appendix Table 2. Covariate Correlations between Measures of Parental Deployment and Control Variables Dependent Variable: Measure of Parental Deployment Metric, by Time Period

\begin{tabular}{|c|c|c|c|c|c|c|c|}
\hline & \multirow[b]{2}{*}{$\begin{array}{l}\text { Population } \\
\text { Mean } \\
\{\text { Std. Dev. }\}\end{array}$} & \multicolumn{2}{|c|}{ A. Current School Year } & \multicolumn{2}{|c|}{ B. Past Five Years } & \multicolumn{2}{|c|}{ C. Instrumental Variables } \\
\hline & & $\begin{array}{c}\text { Ever } \\
\text { Deployed } \\
\text { (1) }\end{array}$ & $\begin{array}{l}\text { Months } \\
\text { Deployed } \\
\text { (2) }\end{array}$ & $\begin{array}{c}\text { Ever } \\
\text { Deployed } \\
\text { (1) }\end{array}$ & $\begin{array}{l}\text { Months } \\
\text { Deployed } \\
\text { (2) }\end{array}$ & $\begin{array}{l}\text { One-Third of } \\
\text { Unit Deployed } \\
\text { (1) }\end{array}$ & $\begin{array}{l}\text { Average Months } \\
\text { Deployed for the } \\
\text { Assigned Unit } \\
\text { (2) }\end{array}$ \\
\hline $\begin{array}{l}\text { Male } \\
\text { Child }\end{array}$ & $\begin{array}{c}0.493 \\
\{0.500\}\end{array}$ & $\begin{array}{c}-0.001 \\
(0.004)\end{array}$ & $\begin{array}{c}0.001 \\
(0.017)\end{array}$ & $\begin{array}{c}-0.003 \\
(0.005)\end{array}$ & $\begin{array}{l}-0.036 \\
(0.059)\end{array}$ & $\begin{array}{l}-0.001 \\
(0.003)\end{array}$ & $\begin{array}{l}-0.005 \\
(0.014)\end{array}$ \\
\hline $\begin{array}{l}\text { Black } \\
\text { Child }\end{array}$ & $\begin{array}{c}0.322 \\
\{0.467\}\end{array}$ & $\begin{array}{l}-0.026 \\
(0.005)\end{array}$ & $\begin{array}{l}-0.119 \\
(0.023)\end{array}$ & $\begin{array}{l}-0.039 \\
(0.006)\end{array}$ & $\begin{array}{l}-0.374 \\
(0.077)\end{array}$ & $\begin{array}{l}-0.009 \\
(0.004)\end{array}$ & $\begin{array}{l}-0.092 \\
(0.019)\end{array}$ \\
\hline $\begin{array}{l}\text { Other Race } \\
\text { Child }\end{array}$ & $\begin{array}{c}0.304 \\
\{0.460\}\end{array}$ & $\begin{array}{l}-0.013 \\
(0.005)\end{array}$ & $\begin{array}{l}-0.029 \\
(0.022)\end{array}$ & $\begin{array}{l}-0.017 \\
(0.006)\end{array}$ & $\begin{array}{l}-0.116 \\
(0.074)\end{array}$ & $\begin{array}{l}-0.003 \\
(0.003)\end{array}$ & $\begin{array}{l}-0.035 \\
(0.018)\end{array}$ \\
\hline $\begin{array}{l}\text { Parents } \\
\text { Married }\end{array}$ & $\begin{array}{c}0.921 \\
\{0.269\}\end{array}$ & $\begin{array}{c}0.000 \\
(0.007)\end{array}$ & $\begin{array}{l}-0.043 \\
(0.033)\end{array}$ & $\begin{array}{l}-0.011 \\
(0.009)\end{array}$ & $\begin{array}{l}-0.256 \\
(0.107)\end{array}$ & $\begin{array}{l}-0.009 \\
(0.005)\end{array}$ & $\begin{array}{l}-0.055 \\
(0.027)\end{array}$ \\
\hline $\begin{array}{l}\text { Father is } \\
\text { in the Army }\end{array}$ & $\begin{array}{c}0.881 \\
\{0.323\}\end{array}$ & $\begin{array}{c}0.142 \\
(0.006)\end{array}$ & $\begin{array}{c}0.600 \\
(0.025)\end{array}$ & $\begin{array}{c}0.218 \\
(0.009)\end{array}$ & $\begin{array}{c}2.141 \\
(0.088)\end{array}$ & $\begin{array}{c}0.069 \\
(0.004)\end{array}$ & $\begin{array}{c}0.357 \\
(0.021)\end{array}$ \\
\hline $\begin{array}{c}\text { Parent is a } \\
\text { High School Drop Out }\end{array}$ & $\begin{array}{c}0.006 \\
\{0.080\}\end{array}$ & $\begin{array}{c}0.069 \\
(0.025)\end{array}$ & $\begin{array}{c}0.314 \\
(0.126)\end{array}$ & $\begin{array}{c}0.080 \\
(0.028)\end{array}$ & $\begin{array}{c}0.825 \\
(0.369)\end{array}$ & $\begin{array}{c}0.033 \\
(0.020)\end{array}$ & $\begin{array}{c}0.295 \\
(0.111)\end{array}$ \\
\hline $\begin{array}{l}\text { Parent has } \\
\text { Some College }\end{array}$ & $\begin{array}{c}0.204 \\
\{0.403\}\end{array}$ & $\begin{array}{l}-0.017 \\
(0.005)\end{array}$ & $\begin{array}{l}-0.105 \\
(0.021)\end{array}$ & $\begin{array}{l}-0.039 \\
(0.007)\end{array}$ & $\begin{array}{l}-0.493 \\
(0.072)\end{array}$ & $\begin{array}{l}-0.023 \\
(0.003)\end{array}$ & $\begin{array}{l}-0.122 \\
(0.017)\end{array}$ \\
\hline $\begin{array}{l}\text { Parent has a } \\
\text { College Degree }\end{array}$ & $\begin{array}{c}0.067 \\
\{0.249\}\end{array}$ & $\begin{array}{l}-0.029 \\
(0.008)\end{array}$ & $\begin{array}{l}-0.160 \\
(0.036)\end{array}$ & $\begin{array}{l}-0.058 \\
(0.011)\end{array}$ & $\begin{array}{l}-0.584 \\
(0.132)\end{array}$ & $\begin{array}{l}-0.036 \\
(0.005)\end{array}$ & $\begin{array}{l}-0.181 \\
(0.028)\end{array}$ \\
\hline $\begin{array}{c}\text { Parent has a } \\
\text { Graduate Degree }\end{array}$ & $\begin{array}{c}0.009 \\
\{0.093\}\end{array}$ & $\begin{array}{l}-0.077 \\
(0.020)\end{array}$ & $\begin{array}{l}-0.431 \\
(0.081)\end{array}$ & $\begin{array}{l}-0.108 \\
(0.028)\end{array}$ & $\begin{array}{l}-1.622 \\
(0.272)\end{array}$ & $\begin{array}{l}-0.076 \\
(0.011)\end{array}$ & $\begin{array}{l}-0.383 \\
(0.068)\end{array}$ \\
\hline $\begin{array}{l}\text { Parent AFQT } \\
\text { (Cat } 1 \text { \& 2) }\end{array}$ & $\begin{array}{c}0.309 \\
\{0.462\}\end{array}$ & $\begin{array}{l}-0.001 \\
(0.005)\end{array}$ & $\begin{array}{l}-0.008 \\
(0.023)\end{array}$ & $\begin{array}{c}0.002 \\
(0.007)\end{array}$ & $\begin{array}{l}-0.032 \\
(0.081)\end{array}$ & $\begin{array}{l}-0.005 \\
(0.004)\end{array}$ & $\begin{array}{l}-0.016 \\
(0.019)\end{array}$ \\
\hline $\begin{array}{l}\text { Parent AFQT } \\
\text { (Cat 3B) }\end{array}$ & $\begin{array}{c}0.358 \\
\{0.479\}\end{array}$ & $\begin{array}{c}0.006 \\
(0.005)\end{array}$ & $\begin{array}{c}0.054 \\
(0.022)\end{array}$ & $\begin{array}{c}0.008 \\
(0.007)\end{array}$ & $\begin{array}{c}0.135 \\
(0.076)\end{array}$ & $\begin{array}{c}0.008 \\
(0.003)\end{array}$ & $\begin{array}{c}0.043 \\
(0.018)\end{array}$ \\
\hline $\begin{array}{l}\text { Parent AFQT } \\
\text { (Cat } 4 \text { \& Cat 5) }\end{array}$ & $\begin{array}{c}0.068 \\
\{0.253\}\end{array}$ & $\begin{array}{l}-0.025 \\
(0.008)\end{array}$ & $\begin{array}{l}-0.107 \\
(0.035)\end{array}$ & $\begin{array}{l}-0.027 \\
(0.012)\end{array}$ & $\begin{array}{l}-0.298 \\
(0.124)\end{array}$ & $\begin{array}{l}-0.010 \\
(0.006)\end{array}$ & $\begin{array}{l}-0.090 \\
(0.029)\end{array}$ \\
\hline $\begin{array}{c}\text { Combat } \\
\text { Support Branch }\end{array}$ & $\begin{array}{c}0.165 \\
\{0.371\}\end{array}$ & $\begin{array}{l}-0.008 \\
(0.006)\end{array}$ & $\begin{array}{l}-0.064 \\
(0.026)\end{array}$ & $\begin{array}{l}-0.044 \\
(0.008)\end{array}$ & $\begin{array}{l}-0.412 \\
(0.096)\end{array}$ & $\begin{array}{l}-0.018 \\
(0.004)\end{array}$ & $\begin{array}{l}-0.055 \\
(0.021)\end{array}$ \\
\hline $\begin{array}{l}\text { Combat Service } \\
\text { Support Branch }\end{array}$ & $\begin{array}{c}0.435 \\
\{0.496\}\end{array}$ & $\begin{array}{l}-0.009 \\
(0.005)\end{array}$ & $\begin{array}{l}-0.014 \\
(0.021)\end{array}$ & $\begin{array}{l}-0.048 \\
(0.006)\end{array}$ & $\begin{array}{l}-0.558 \\
(0.071)\end{array}$ & $\begin{array}{l}-0.008 \\
(0.003)\end{array}$ & $\begin{array}{c}0.015 \\
(0.017)\end{array}$ \\
\hline $\begin{array}{l}\text { Special } \\
\text { Branch }\end{array}$ & $\begin{array}{c}0.080 \\
\{0.272\}\end{array}$ & $\begin{array}{l}-0.061 \\
(0.008)\end{array}$ & $\begin{array}{l}-0.258 \\
(0.034)\end{array}$ & $\begin{array}{l}-0.161 \\
(0.011)\end{array}$ & $\begin{array}{l}-1.620 \\
(0.111)\end{array}$ & $\begin{array}{l}-0.046 \\
(0.005)\end{array}$ & $\begin{array}{l}-0.276 \\
(0.027)\end{array}$ \\
\hline Intercept & & $\begin{array}{l}-0.006 \\
(0.010)\end{array}$ & $\begin{array}{l}-0.103 \\
(0.045)\end{array}$ & $\begin{array}{c}0.293 \\
(0.014)\end{array}$ & $\begin{array}{c}1.795 \\
(0.153)\end{array}$ & $\begin{array}{c}0.004 \\
(0.007)\end{array}$ & $\begin{array}{c}0.142 \\
(0.037)\end{array}$ \\
\hline $\mathrm{R}^{2}$ & & 0.10 & 0.13 & 0.10 & 0.15 & 0.09 & 0.16 \\
\hline Observations & 56,116 & 56,116 & 56,116 & 56,116 & 56,116 & 56,116 & 56,116 \\
\hline
\end{tabular}

Standard errors (in parenthesis) account for clustering at the individual child level because some children appear in multiple years. Regressions are estimated by OLS and contain a constant and dummies for the year of exam and for grade levels 4 through 11 . The full set of child and parental controls are presented in Table 2. See notes in Table 1 for additional sample description. The $R^{2}$ in the baseline regression with only child controls explains all but 1 to 2 percent of the total variation from the full specification as shown in the $R^{2}$ above. 


\begin{tabular}{|c|c|c|c|c|c|c|c|c|c|c|}
\hline & \multicolumn{5}{|c|}{ A. Ever Deployed } & \multicolumn{5}{|c|}{ B. Months Deployed } \\
\hline & $\begin{array}{l}\text { OLS } \\
(1)\end{array}$ & $\begin{array}{l}\text { OLS } \\
(2)\end{array}$ & $\begin{array}{l}\text { OLS } \\
(3)\end{array}$ & $\begin{array}{l}2 S L S \\
(4)\end{array}$ & $\begin{array}{l}2 S L S \\
(5)\end{array}$ & $\begin{array}{l}\text { OLS } \\
(1)\end{array}$ & $\begin{array}{l}\text { OLS } \\
(2)\end{array}$ & $\begin{array}{l}\text { OLS } \\
(3)\end{array}$ & $\begin{array}{l}2 S L S \\
(4)\end{array}$ & $\begin{array}{l}2 \text { SLS } \\
(5)\end{array}$ \\
\hline Ever Deployed & $\begin{array}{l}-0.419 \\
(0.149)\end{array}$ & $\begin{array}{l}-0.423 \\
(0.151)\end{array}$ & $\begin{array}{l}-0.397 \\
(0.239)\end{array}$ & $\begin{array}{l}-0.557 \\
(0.235)\end{array}$ & $\begin{array}{l}-0.565 \\
(0.281)\end{array}$ & & & & & \\
\hline Months Deployed & & & & & & $\begin{array}{l}-0.112 \\
(0.028)\end{array}$ & $\begin{array}{l}-0.116 \\
(0.028)\end{array}$ & $\begin{array}{l}-0.082 \\
(0.051)\end{array}$ & $\begin{array}{l}-0.136 \\
(0.033)\end{array}$ & $\begin{array}{l}-0.136 \\
(0.040)\end{array}$ \\
\hline $\begin{array}{l}\text { Male } \\
\text { Child }\end{array}$ & $\begin{array}{l}-2.159 \\
(0.162)\end{array}$ & $\begin{array}{l}-2.133 \\
(0.166)\end{array}$ & $\begin{array}{l}-2.116 \\
(0.255)\end{array}$ & $\begin{array}{l}-2.159 \\
(0.162)\end{array}$ & $\begin{array}{l}-2.159 \\
(0.141)\end{array}$ & $\begin{array}{l}-2.158 \\
(0.162)\end{array}$ & $\begin{array}{l}-2.132 \\
(0.166)\end{array}$ & $\begin{array}{l}-2.115 \\
(0.255)\end{array}$ & $\begin{array}{l}-2.158 \\
(0.162)\end{array}$ & $\begin{array}{l}-2.158 \\
(0.141)\end{array}$ \\
\hline $\begin{array}{l}\text { Black } \\
\text { Child }\end{array}$ & $\begin{array}{l}-5.124 \\
(0.211)\end{array}$ & $\begin{array}{l}-5.162 \\
(0.215)\end{array}$ & $\begin{array}{l}-5.962 \\
(0.321)\end{array}$ & $\begin{array}{l}-5.128 \\
(0.211)\end{array}$ & $\begin{array}{l}-5.128 \\
(0.209)\end{array}$ & $\begin{array}{l}-5.126 \\
(0.211)\end{array}$ & $\begin{array}{l}-5.165 \\
(0.215)\end{array}$ & $\begin{array}{l}-5.967 \\
(0.321)\end{array}$ & $\begin{array}{l}-5.129 \\
(0.211)\end{array}$ & $\begin{array}{l}-5.129 \\
(0.208)\end{array}$ \\
\hline $\begin{array}{l}\text { Other Race } \\
\text { Child }\end{array}$ & $\begin{array}{l}-0.885 \\
(0.199)\end{array}$ & $\begin{array}{l}-0.834 \\
(0.201)\end{array}$ & $\begin{array}{l}-0.967 \\
(0.314)\end{array}$ & $\begin{array}{l}-0.887 \\
(0.199)\end{array}$ & $\begin{array}{l}-0.887 \\
(0.187)\end{array}$ & $\begin{array}{l}-0.883 \\
(0.199)\end{array}$ & $\begin{array}{c}-0.832 \\
(0.201)\end{array}$ & $\begin{array}{l}-0.967 \\
(0.314)\end{array}$ & $\begin{array}{l}-0.884 \\
(0.199)\end{array}$ & $\begin{array}{l}-0.884 \\
(0.187)\end{array}$ \\
\hline 1st Stage & & & & $\begin{array}{c}0.698 \\
(0.004)\end{array}$ & $\begin{array}{c}0.699 \\
(0.008)\end{array}$ & & & & $\begin{array}{l}1.024 \\
(0.004)\end{array}$ & $\begin{array}{c}1.024 \\
(0.006)\end{array}$ \\
\hline Full Specification & Yes & No & No & Yes & No & Yes & No & No & Yes & No \\
\hline $\begin{array}{l}\text { Drops Joint Military } \\
\text { Families }\end{array}$ & No & Yes & No & No & No & No & Yes & No & No & No \\
\hline $\begin{array}{l}\text { Drops Children Not in } \\
\text { coNUS Schools and } \\
\text { arents Not Assigned to } \\
\text { CONUS Locations }\end{array}$ & No & No & Yes & No & No & No & No & Yes & No & No \\
\hline $\begin{array}{l}\text { Oluster SE on Parents } \\
\text { Unit Rather Than on } \\
\text { Individual Child }\end{array}$ & No & No & No & No & Yes & No & No & No & No & Yes \\
\hline $\mathrm{R}^{2}$ & 0.09 & 0.09 & 0.10 & 0.28 & 0.28 & 0.09 & 0.09 & 0.10 & 0.63 & 0.63 \\
\hline Observations & 56,116 & 54,090 & 20,360 & 56,116 & 56,116 & 56,116 & 54,090 & 20,360 & 56,116 & 56,116 \\
\hline
\end{tabular}




\section{Figure I. Assigning Soldiers to Units}

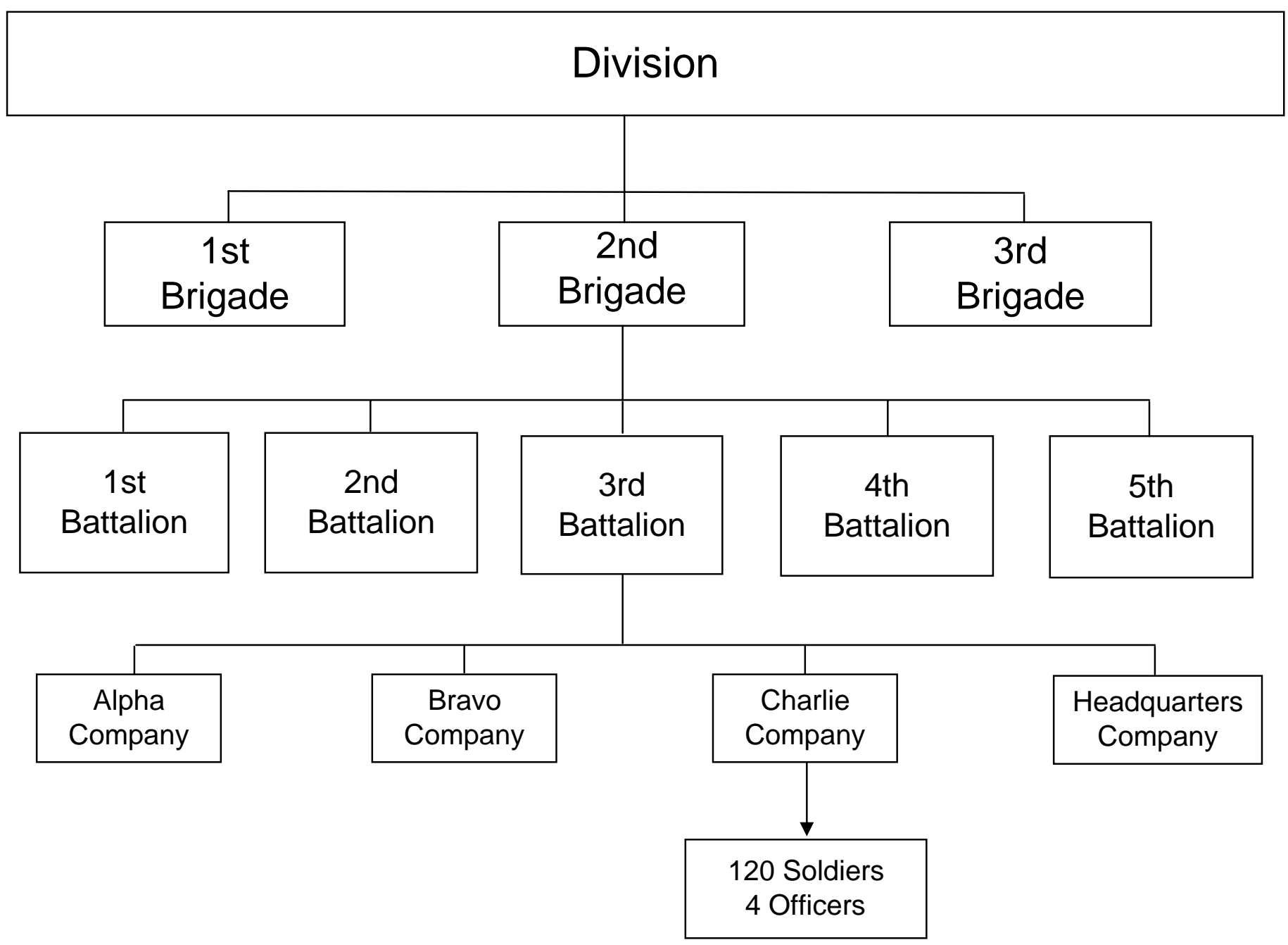

Notes: For deployment purposes, soldiers in the headquarters company are assigned to one of the three primary maneuver companies: Alpha, Bravo, and Charlie. 